\title{
Osmotic adjustment and up-regulation expression of stress-responsive genes in tomato induced by soil salinity resulted from nitrate fertilization
}

\author{
Tingting Chang ${ }^{1,2^{*}}$, Yujie Zhang ${ }^{1,2}$, Huilian $\mathrm{Xu}^{3}$, Xiaohou Shao ${ }^{1,2}$, Qicong $\mathrm{Xu}^{3}$, \\ Fenglan $\mathrm{Li}^{4}$, Lina $\mathrm{Yu}^{5}$, Zhanyu Zhang ${ }^{1,2}$ \\ (1. Key Laboratory of Efficient Irrigation-Drainage and Agricultural Soil-Water Environment in Southern China of Ministry of Education, \\ Hohai University, Nanjing 210098, China; 2. College of Agricultural Science and Engineering, Hohai University, Nanjing210098, China; \\ 3. International Nature Farming Research Center, Matsumoto390-1401 Japan; \\ 4. Northeast Agricultural University, Harbin 150000, China; 5. Rizhao Institute of Agricultural Sciences, Rizhao276800, China)
}

\begin{abstract}
Concerns about the soil salinity caused by excessive fertilization have prompted scientists to clarify the detailed mechanisms and find techniques to alleviate the damage caused by this kind of soil salinity. Aims of this study were to elucidate the effect of soil salinity caused by nitrate fertilization and the differences in salinity effect between nitrate salts and $\mathrm{NaCl}$ salt with analyses at various levels of crop physiology and molecular biology. A microbial inoculation was also tried to verify whether it could alleviate the salinity-induced loss and damages. In three experiments (Exp I, II and III), nitrate salts (NS) of $\mathrm{Ca}\left(\mathrm{NO}_{3}\right)_{2}$ and $\mathrm{KNO}_{3}$ were applied to potted tomato plants to simulate the soil salinity caused by fertilization and a microbial inoculant (MI) was applied. Photosynthesis was measured using Li-6400. Osmotic adjustment was analyzed using the mathematically modeled pressure-volume curve; $\mathrm{O}_{2}{ }^{-}$concentration and activity of SOD and nitrate reductase were measured. Expression of nitrate reductase gene and the stress-responsive gene DREB2 was analyzed using the real-time PCR method. In Exp I and II, where the applied NS amount was moderate, NS application at low concentration induced increases in $\mathrm{O}_{2}{ }^{-}$and MDA concentrations and plants acclimated to the soil salinity as the treatment prolonged for weeks. The acclimation was contributed by osmotic adjustment, activation of SOD and re-compartmentation of cell water between symplasm and apoplasm. These adjustments might be ultimately attributed to up-regulation of stress-responsive genes such as DREB2 as well as the nitrate reductase (NR) gene. However, in Exp III, applications of $\mathrm{NaCl}$ and $\mathrm{NS}$ at high concentration could not show positive effects as NS did. Application of MI synergistically increased the xerophytophysiological regulation caused by NS and alleviated the salinity damage in addition to its own positive effects on the tomato plants. Different from $\mathrm{NaCl}$, nitrate salts at low application rate increased the total biomass and fruit yield of tomato and induced up-regulation expression of stress-responsive genes and the consequent active osmotic adjustment. However, nitrate application at high level negatively affected tomato plants irrespective of the gene up-regulations. Application of MI alleviated the salinity damage and synergistically increased the xerophytophysiological regulation caused by the soil salinity in addition to its positive effects on the tomato crop but the detailed mechanisms needed to be clarified in future further studies.
\end{abstract}

Keywords: nitrate fertilizer, osmotic adjustment, salinity stress, soil salinization, tomato (Solanum lycopersicum); xerophytophysiology, microorganism, bioremediation

DOI: $10.25165 /$ j.ijabe.20181103.2952

Citation: Chang T T, Zhang Y J, Xu H L, Shao X H, Xu Q C, Li F L, et al. Osmotic adjustment and up-regulation expression of stress-responsive genes in tomato induced by soil salinity resulted from nitrate fertilization. Int J Agric \& Biol Eng, 2018; 11(3): 126-136.

\section{Introduction}

Nitrate is the primary form of nitrogen nutrient in agricultural

Received date: 2016-10-28 Accepted date: 2018-03-23

Biographies: Yujie Zhang, MS, research interests: soil science, saline soil amendment, Email: 972928297@qq.com; Huilian Xu, PhD, Professor, research interests: soil science, crop physiology, Email: huilian@infrc.or.jp; Xiaohou Shao, $\mathrm{PhD}$, Professor, research interests: agriculture water and soil engineering, saline soil amendment, Email: shaoxiaohou@163.com; Qicong Xu, PhD, Associate Professor, research interests: soil science, crop physiology, Email: 254331977@qq.com; Fenglan Li, PhD, Associate Professor, research interests: soil science, crop physiology, Email: 459843587@qq.com; Lina Yu, MS, Associate Professor, research interests: soil science, crop physiology, Email: 914891618@qq.com; Zhanyu Zhang, PhD, Professor, research interests: agriculture water and soil engineering, saline soil amendment, Email: 19870053@hhu.edu.cn.

*Corresponding author: Tingting Chang, $\mathrm{PhD}$, Associate Professor, research interests: agriculture water and soil engineering, saline soil amendment, Mailing address: Xikang Road 1, Gulou district, Nanjing, China. Tel: +8615951906899, Email: changtingting225@163.com. soils ${ }^{[1]}$. However, one of the consequences of the excessive application of nitrogen fertilizers is soil salinization caused by nitrate accumulation ${ }^{[2-4]}$ in addition to food contamination ${ }^{[5]}$ and environment pollution ${ }^{[6,7]}$. Production practices and studies by pioneers have found these problems and these problems have prompted scientists and policymakers to conduct field surveys and experiments to examine the impact of nitrate accumulation on environment and food quality, especially the secondary soil salinization. Now it is clearly known that the excessive nitrate accumulation is mainly caused by input of nitrogen fertilizers and animal manures at rates higher than crop requirements. Unfortunately, this problem has not yet been payed enough attention. Actually, the effect of fertilizers on soil salinity is not immediately obvious because the soil has strong buffering capacity to its salt content ${ }^{[8,9]}$. However, long-term overload of chemical fertilization has caused soil degradation and loss of its buffering capacity. Soil salinization is often attributed to sodium and potassium contained in fertilizers. However, it is neglected that 
nitrate must be paired with cations at existence in soils. Obviously, excessive nitrate accumulation contributes to soil salinization no matter whether cations or nitrate impose more effect on the salinity ${ }^{[10]}$. Accumulation to high level of nitrate in soils may be caused by excessive applications of nitrogen fertilizers, in either urine or nitrate form, and even in organic forms. Nitrate at high concentration causes soil salinity shown by high soil EC and many other problems in crop production, especially in soil-based greenhouses $^{[12-14]}$. In the extreme case in China, 15 tons of chemical fertilizers and $30 \mathrm{~m}^{3}$ of compost are applied to 1 ha of soil-based greenhouse land to ensure the highest yield of vegetable through the whole year ${ }^{[13,14]}$. Therefore, farmers have to totally change the greenhouse soils every three years to solve the salinity problems ${ }^{[15]}$. Different from cations such as sodium that cause soil salinity, nitrate is the essential nutrient to plants in a hand although its excessive accumulations in soils and food plants cause profound problems in environment and in food quality ${ }^{[7]}$. Soil salinity causes plant water stress, ionic imbalance, mineral nutrition deficiency, photosynthetic inhibition, carbon allocation and utilization and the final reduction in productivity of crops including tomatoes $^{[16-19]}$. Nevertheless, as one of the soil salinity source, nitrate is different from the cations such as $\mathrm{Na}^{+}$and $\mathrm{K}^{+[20]}$ because nitrate is a main essential nutrient to plants ${ }^{[10]}$. It is difficult to separate the injurious effect caused by salinity from the positive nutritional effect of nitrate. It is important to clarify how nitrogen fertilization causes soil salinization and what consequence in plant growth and physiology would be induced by the soil salinity caused by the excessive nitrate accumulation. Therefore, in the present study, the focus was placed on the soil salinity caused by excessive nitrate application and its effect on plant growth and physiology in potted tomato crops, in aspects of photosynthetic activities, turgor maintenance from osmotic adjustment, and the final fruit yield. Moreover, excessive accumulation of nitrate in soil may also cause excessive accumulation of nitrate in plant body, which may interfere with nitrogen metabolism. The nitrogen metabolism started from nitrate and nitrate reductase (NR) occupies a central position in nitrogen metabolism in higher plants ${ }^{[21,22]}$. The nitrate reductase is encoded by the NR gene ${ }^{[23,24]}$. Although the nitrate reductase and the NR gene are subjected to complex regulation mechanisms, the activity of the enzyme and expression of the gene are induced and regulated by nitrate itself ${ }^{[25-29]}$. Therefore, in the present study, activity of nitrate reductase and the expression of the gene coding for NR were examined to elucidate the effect of nitrate accumulation in soil. Moreover, as mentioned above, salinity caused by excessive nitrogen fertilization may induce xerophytophysiological regulations such as osmotic adjustment and the consequent leaf turgor maintenance in order to alleviate damages by the stresses. These adaptation and adjustment processes are ultimately controlled by the stress responsive genes, one of which is $D R E B 2^{[30]}$. In the first step, crisis signal substances including abscisic acid, jasmonic acid and oxygen radical are induced and a cascade of signal transduction is involved $^{[31]}$. One of the easily detected signal substances is $\mathrm{O}_{2}{ }^{-}$. Accumulation of $\mathrm{O}_{2}^{-}$may induce synthesis and activation of the antioxidant enzymes such as SOD and in turn the antioxidant enzymes can delete $\mathrm{O}_{2}{ }^{-}$and damages are avoided or alleviated ${ }^{[32]}$. Therefore, in the present study, antioxidant function and induced up-regulation express of the stress-responsive gene were examined. Many practice have been tried to alleviate the injurious effect of soil salinity, by providing adequate drainage ${ }^{[33]}$, growing salt tolerant varieties ${ }^{[34]}$, applying inorganic and organic amendments, and maintaining adequate soil moisture ${ }^{[35]}$. There are also many research cases using microbial materials in alleviating soil salinity. However, the microbes used are different in their sources and effectiveness. Bashan ${ }^{[36]}$ evaluated bacterial inoculants used in agriculture with emphasis on semiarid agriculture including salinity and drought stresses. Dodd and Perez-Alfocea ${ }^{[37]}$ indicated the beneficial physiological effects of microorganisms including improved nutrient and water uptake, growth promotion, and alteration of plant hormonal status and metabolism by alleviating stresses such salinity, with special reference to signaling mechanisms that interact with key physiological processes to improve plant tolerance to the osmotic and toxic components of salinity. They conclude that the improved plant nutrition is a general beneficial effect and may contribute to the maintenance of homeostasis of toxic ions under saline stress. Mayak ${ }^{[38]}$ reported that bacteria populating arid and salty environments conferred resistance in tomato and pepper plants to water stress. They found one of these strains, Achromobacter piechaudii ARV8, which significantly increased the fresh and dry weights of both tomato and pepper seedlings exposed to transient water stress. In the present study, a microbial inoculant, with yeast, lactic acid bacteria and actinomycetes as the main species, was tried as an amendment to alleviate the soil salinity and the injurious effects caused by excessive nitrate accumulation in soil. This inoculant has been used by farmers in Japan and many other countries although the related research lags behind. Xu's research group had tried this microbial inoculant in saline soil improvement in the Yellow River Delta area and found that it was effective in alleviation of soil salinity by improving soil aggregation ${ }^{[39]}$. However, it is not clear whether the same microbial inoculant is effective in alleviation of the secondary salinity caused by excessive use of nitrogen fertilizers. Therefore, in the present study, the microbial inoculant was just first used as the practice to test whether it could reduce the salinity injury and the detailed mechanisms may be considered in the future research.

\section{Materials and methods}

\subsection{Plant materials and treatments}

Three experiments (Exp I, II and II) were conducted with potted plants of tomato (Solanum lycopersicum L. cv. Myoko) with treatments changed in different experiments.

\subsubsection{Exp I}

Tomato seedlings were transplanted in Wagner's pots with a soil surface of $0.05 \mathrm{~m}^{2}$ and a height of $30 \mathrm{~cm}$ in early July and grown under a rainout shelter. The soil is an Andosol and the chemical properties before fertilization, after treatment and after plant harvest are presented in Table 1. The soil in each pot was fertilized with $45 \mathrm{~g}$ of organic fertilizer (N, 5.2, P, 30, K, $20 \mathrm{~g} / \mathrm{kg}$ ), which was fermented with oil mill sludge, rice bran and fish meal. Because the treatments were related with chemical fertilizer application, in plots of the control (CK) chemical fertilizers were avoided and the organic fertilizer was applied to the soil as the base fertilization to support the basic plants growth. Four treatments as 2 (salinity) $\times 2$ (microorganisms) factorial were designed as follows 1) Salinity: salt content of $3.0 \mathrm{~g} / \mathrm{kg}$ by applying $4.2 \mathrm{~g} \mathrm{Ca}\left(\mathrm{NO}_{3}\right)_{2}$ and $4.2 \mathrm{~g} \mathrm{KNO}_{3}$ to each pot; 2) Salinity-MI: Treatment 1) with $10 \mathrm{ml}$ of microbial inoculant (MI) applied into the soil; 3) CK: without salt application; 4) CK-MI: CK with $10 \mathrm{ml}$ of MI applied. The microbial inoculant contains lactic bacteria (Lactobacillus plantarum), yeasts (Saccharomyces cerevisiae), actinomycetes (Streptomyces albus) and photosynthetic bacteria 
(Rhodopseudomonas palustris) as main components at $\mathrm{pH} 3.5$ with a commercial name as EM (EM Laboratory Co., Ltd., Shizuoka, Japan). The four treatments were arranged in a $4 \times 4$ Latin Square under a rainout shelter with 8 pots per plot. The microbial inoculant (MI) is developed by International Nature Farming Research Center (Matsumoto city, Nagano, Japan) containing a group of beneficial microorganisms as lactic acid bacteria and yeast ${ }^{[40]}$. The liquid product of this microbial inoculant reaches pH 3.5 with total microbial density within $10^{10}-10^{12} \mathrm{CPU} \mathrm{mL}^{-1}$. Five weeks after seedlings transplanted, the plants entered the flowering stage. Then, treatments were imposed to the pots. Samples were taken from the 5th leaf from the top $6 \mathrm{~h}, 7$ day and 35 days after treatments started. The sample used for nitrate reductase activity measurement was $0.5 \mathrm{~g}$ and that for RNA extraction was $0.1 \mathrm{~g}$. Leaf photosynthesis was measured 30 days after treatments started and analyses of Pressure-Volume curve and excised leaf transpiration declining curve were also conducted at this time.

\subsubsection{Exp II}

Experiment was conducted in artificial growth chambers inside laboratory to confirm Exp I only at levels of the molecular biology and biochemistry with young plants. Other factors such as fruit yield and soil properties were not considered in this small pot experiment. The light intensity was $160 \mu \mathrm{mol} / \mathrm{m}^{2} \cdot \mathrm{s}$ over the canopy of the tomato seedlings. Temperature was controlled at $(22 \pm 1 / 20 \pm 1)^{\circ} \mathrm{C}$ (day/night). The relative air humidity was $(60 \pm 1) \%$. Polyethylene pots with a soil surface of $0.001 \mathrm{~m}^{2}$ and a height of $15 \mathrm{~cm}$. The pots were filled with a commercial peat-moss based substrate with N, P and K (N-P-K=150-800$150 \mathrm{mg} / \mathrm{L}$ ) fertilized ready. In addition, treatments were made as follows:1) CK: without additional fertilization, 2) NS: the soil salt concentration of $30 \mathrm{~g} / \mathrm{kg}$ with $\mathrm{Ca}\left(\mathrm{NO}_{3}\right)_{2}$ and $\left.\mathrm{KNO}_{3}, 3\right) \mathrm{CS}$ : the soil salt concentration of $30 \mathrm{~g} / \mathrm{kg}$ with $\mathrm{CaCl}_{2}$ and $\mathrm{NaCl}$, 4) MI, 5) $\mathrm{MN}$ and 6) $\mathrm{MC}$ were added with microbial inoculant (MI, the same as in Exp I) in addition to 1) CK, 2) NS and 3) CS. The microbial inoculate in $\mathrm{ml}$ was diluted 100 times added to each pot of treatments of 4), 5) and 6). Leaf sample used for analyses in biochemistry and molecular biology were taken $3 \mathrm{~d}, 8 \mathrm{~d}$ and $15 \mathrm{~d}$ after treatments started. Photosynthesis measurement and analyses of Pressure-Volume curve and excised leaf transpiration declining curve were made $21 \mathrm{~d}$ after treatments started.

\subsubsection{Exp III}

Small plastic pots were used as the same in Exp I. The purpose of Exp III was used to firm Exp II at a further higher salinity level. Management of plant materials and examined variables were the same as described in Exp II with only concentration of salts doubled.

\subsection{Measurement of leaf photosynthesis and leaf color}

Leaf photosynthesis was measured and analyzed according to $\mathrm{Xu}$ et al. ${ }^{[40]}$. Leaf color was measured in situ using a chlorophyll meter (SPAD-502, Konica Minolta, Osaka, Japan).

\subsubsection{Measurement of glucose concentrations in fruit}

Glucose were measured by a reflectometer (RQflex 10, Merck KGaA, Darmstadt, Germany) following the manual instruction.

2.2.2 Estimation of osmotic adjustment by analyzing the pressure-volume curve

After the photosynthetic measurement, the leaf was excised with 5 leaflets attached. The excised leaf was rehydrated overnight with the cut trace in water under saturated humidity at $15^{\circ} \mathrm{C}$. Then the leaf was used for the pressure-volume $(\mathrm{P}-\mathrm{V})$ analysis according to $\mathrm{Xu}$ et al. ${ }^{[30]}$. The P-V curve was modeled as
$-\Psi^{-1}=\left\{\Psi_{\mathrm{FT}}{ }^{-1}-\pi_{\mathrm{s}+\mathrm{a}}{ }^{-1}\left[\zeta_{\mathrm{o}}-\beta(1-\zeta)-\zeta_{\mathrm{ap}}\right]\right\} \mathrm{e}^{-\alpha(1-\zeta)}+\pi_{\mathrm{s}+\mathrm{a}}{ }^{-1}\left[\zeta_{\mathrm{o}}-\beta(1-\zeta)-\zeta_{\mathrm{ap}}\right]$. In the equation, $\Psi$ was leaf water potential; $\pi$ was osmotic potential; $\zeta$ was relative water content; subscripts FT, sym, ap and s+a mean full turgid, symplast, apoplast, and symplast + apoplast, respectively. The concentration of osmolytes $\left(C_{\text {osm }}\right)$ was calculated as $C_{\text {osm }}=-410 \pi^{[40,41]}$.

2.2.3 Assessment of leaf water retention ability by analyzing the excised leaf transpiration declining curve

The leaf was excised under water, rehydrated overnight and then placed under light of $450 \mu \mathrm{mol} / \mathrm{m}^{2} \cdot \mathrm{s}$. At 2-5 min intervals, fresh mass was recorded and the relative water content was calculated. A curve, with time $(t)$ as abscissa and relative water content $(\zeta)$ as the ordinate, was modeled as $\zeta=\left[\zeta_{0}-\zeta_{\mathrm{SC}}\left(1-\beta^{\prime} t\right)\right]$ $\mathrm{e}^{-\alpha^{\prime} t}+\zeta_{\mathrm{SC}}\left(1-\beta^{\prime} t\right)$, where $\left.\beta^{\prime} t\right)$ and $\alpha^{\prime}$ were constants. The subscripts 0 and SC mean "saturated" and "stomatal closed",[40]. The time used to theoretically dry up the leaf to its relative water content $(\tau)$ of $10 \%$ was calculated.

\subsubsection{Determination of activities of nitrate reductase}

The leaf samples were stored in a $-85^{\circ} \mathrm{C}$ freezer for use. The frozen sample was ground in liquid $\mathrm{N}$ in a chilled mortar. The extraction buffer contained $100 \mathrm{mM}$ Tris- $\mathrm{HCl}$ at $\mathrm{pH} 7.5,10 \mathrm{mM}$ cysteine, $1 \mathrm{mM}$ EDTA-Na, and $5 \mathrm{mM}$ FAD. The buffer was added to the sample powder, homogenized again and then centrifuged at $15000 \times \mathrm{g}$ for $30 \mathrm{~min}$ under $4^{\circ} \mathrm{C}$, with the supernatant used as enzyme sample. Nitrate reductase activity was measured by sulfanilamide spectrometry according to the manual of Sigma Aldrich (http://www.sigmaaldrich.com).

2.2.5 Analysis of the expression of nitrate reductase gene (NR1)

The expression of NR1 gene was estimated with the real-time PCR system (Eco Real-Time PCR System, Illumina, San Diego, CA). The primer 5.0 was designed according to tomato Actin as the endogenous reference gene. The forward and reverse primers of the internal reference primer were $\mathrm{S} 1$ actin $\mathrm{F}$ : GGAATGGGACAGAAGGAT; S1 actin R: CAGTCAGGAGAACAGGGT with a product size $143 \mathrm{bp}$. The primers of NR1 gene were showed as follows: Forward, (73-91bp) 18 bp 5' GGTTGAGGTGCTTGACTT 3' and Reverse, (233-215bp) 18 bp 5' CTCCCTTGTGAGGTTTGC 3' with a product size of $161 \mathrm{bp}$. Extraction of total RNA was performed using RNeasy Plant Mini Kit (QIAGEN) according to the manual instruction.

2.2.6 Analysis of the expression of the stress-responsive gene (DREB2)

For isolation of $D R E B 2 \mathrm{cDNA}$ from the tomato leaf, the primer was designed as Forward 5'-ATGATAATAATGTCTACAGAGCAA-3' - Reverse 5'-CTAATGTTGCCATAAAA AACTCTC-3'. The cDNA was used as template for PCR with primers as Forward 5'-ATGATAATAATGTCTACAGAGCAA-3' - Reverse 5'-CTAATGTTGCCATAAAAAACTCTC-3'). The specific primers, as Forward 5'-TGGCATCATACTTTCTACAATG-3' Reverse: 5'-CTAATATCCTCGTCACATTTCAT-3', were used for RT-PCR amplification of actin gene. The details were described in Guo and Wang ${ }^{[30]}$.

2.2.7 Measurement of superoxide anion $\left(\mathrm{O}_{2}{ }^{-}\right)$, malondialdehyde (MDA) and Superoxide dismutases (SOD) activity in the tomato leaves

Superoxide anion $\left(\mathrm{O}_{2}^{-}\right)$was measured according to Bissenbaev $^{[32]}$ with some modifications. Activity of superoxide dismutase (SOD) was measured by NBT (riboflavin-nitroblue tetrazolium) $\operatorname{method}^{[42,43]}$. Malondialdehyde (MDA) was 
measured by thiobarbituric acid method ${ }^{[44,45]}$.

\subsubsection{Measurement of soil chemical properties}

Chemical properties were measured using soil samples before fertilization, after nitrate salt application and after plant harvest. Electrical Conductivity (EC) was determined with an extract of soil : water $=1$ : 5 by electrical conductivity meter (CT-57101B/CM-30G, Toa Co., Tokyo, Japan). The same soil extract was used to measure soil $\mathrm{pH}$ using a glass electrode (F-21, Horiba Co., Tokyo, Japan). The total carbon and total nitrogen were determined using an elemental analyzer (CN-Corder MT-700; Yanaco Co., Ltd., Kyoto, Japan). Concentrations of inorganic N and phosphorus were determined by colorimetry method using a photospectrometer (Hitachi U-2000 Tokyo, Japan). Other mineral nutrients were measured with atomic absorption spectroscopy (AA-6200, Shimazu, Kyoto, Japan).

\subsection{Statistic analysis}

The Data from all measurement in the present study were statistically analyzed based on Tukey's multiple comparisons using the software of DPS Data Processing System ${ }^{[46]}$.

\section{Results}

\subsection{Changes in EC}

In Exp I, Wagner's pots each with $15 \mathrm{~L}$ of volume were used and the soil EC was less affected by irrigation compared with Exp II and Exp III, where small plastic pots were used (Table 1). Therefore, soil nutrient and EC were examined only in Exp I. One week after the treatment, nitrate salt application increased soil electrical conductivity (EC), which showed the soil salinity. It was reasonable that nitrate salt application increased total soil nitrogen concentration, inorganic $\mathrm{N}\left(\mathrm{NH}_{4}^{+}\right.$and $\left.\mathrm{NO}_{3}{ }^{-}\right)$concentration and concentrations of $\mathrm{K}$ and $\mathrm{Ca}$ because these elements were included in the nitrate salts. However, application of microbial inoculant could not change EC and most of other parameters. After the plants were harvested, EC and the total and inorganic $\mathrm{N}$ got close without significant difference between treatments because of the plant uptake. $\mathrm{K}$ and $\mathrm{Ca}$ were remained more in salt application plots. There was no clear effect of MI application on the soil properties after plant harvested.

Table 1 Soil nutrients and chemical properties before fertilization, after salt application and after plant harvest (Ep. I)

\begin{tabular}{|c|c|c|c|c|c|c|c|c|c|c|c|}
\hline Plot & $\mathrm{pH}$ & $\begin{array}{c}\mathrm{EC} \\
/ \mathrm{mS} \cdot \mathrm{cm}^{-1}\end{array}$ & $\begin{array}{l}\text { Total C } \\
/ \mathrm{g} \cdot \mathrm{kg}^{-1}\end{array}$ & $\begin{array}{l}\text { Total N } \\
/ \mathrm{g} \cdot \mathrm{kg}^{-1}\end{array}$ & $\begin{array}{c}\mathrm{NH}_{4}^{+} \\
/ \mathrm{mg} \cdot \mathrm{kg}^{-1}\end{array}$ & $\begin{array}{c}\mathrm{NO}_{3}{ }^{-} \\
/ \mathrm{mg} \cdot \mathrm{kg}^{-1}\end{array}$ & $\begin{array}{c}\mathrm{P} \\
/ \mathrm{mg} \cdot \mathrm{kg}^{-1}\end{array}$ & $\frac{\mathrm{K}}{/ \mathrm{g} \cdot \mathrm{kg}^{-1}}$ & $\underset{\mathrm{g} \cdot \mathrm{kg}^{-1}}{\mathrm{Ca}}$ & $\begin{array}{c}\mathrm{Mg} \\
/ \mathrm{cmol}^{-} \mathrm{kg}^{-1}\end{array}$ & $\begin{array}{c}\mathrm{CEC} \\
/ \mathrm{cmol}^{\circ} \mathrm{kg}^{-1}\end{array}$ \\
\hline \multicolumn{12}{|c|}{ Before fertilization } \\
\hline \multicolumn{12}{|c|}{ After nitrate salt application } \\
\hline $\mathrm{CK}$ & 5.92 & $0.056 \mathrm{~b}$ & 48.3 & $3.86 \mathrm{c}$ & $19.2 b$ & $29.3 b$ & 83.7 & $298 b$ & $2.712 \mathrm{c}$ & 0.424 & 19.9 \\
\hline NS & 6.05 & $0.069 \mathrm{a}$ & 47.2 & $4.12 \mathrm{a}$ & $23.2 \mathrm{a}$ & $39.7 \mathrm{a}$ & 79.3 & $419 \mathrm{a}$ & $2.827 \mathrm{~b}$ & 0.433 & 19.2 \\
\hline MI & 5.83 & $0.055 b$ & 47.6 & $3.93 \mathrm{bc}$ & $20.2 b$ & $21.3 \mathrm{c}$ & 81.7 & $312 b$ & $2.782 \mathrm{~b}$ & 0.421 & 19.7 \\
\hline $\mathrm{S}+\mathrm{I}$ & 5.82 & $0.071 \mathrm{a}$ & 48.1 & $4.01 \mathrm{~b}$ & $25.8 \mathrm{a}$ & $35.2 \mathrm{a}$ & 82.7 & $427 \mathrm{a}$ & $2.972 \mathrm{a}$ & 0.442 & 19.8 \\
\hline NS & ns & $* *$ & ns & $*$ & $*$ & $*$ & ns & $* *$ & $*$ & ns & ns \\
\hline MI & ns & ns & ns & ns & $\mathrm{ns}$ & $*$ & ns & ns & ns & ns & ns \\
\hline $\mathrm{S} \times \mathrm{M}$ & $\mathrm{ns}$ & $\mathrm{ns}$ & $\mathrm{ns}$ & ns & $*$ & $*$ & ns & ns & ns & $\mathrm{ns}$ & $\mathrm{ns}$ \\
\hline \multicolumn{12}{|c|}{ After plant harvested } \\
\hline NS & 5.91 & 0.061 & 41.4 & 3.52 & 4.78 & $13.5 \mathrm{a}$ & $42.1 \mathrm{a}$ & $265 b$ & $2.420 \mathrm{ab}$ & 0.404 & 18.4 \\
\hline MI & 5.97 & 0.053 & 41.7 & 3.55 & 5.28 & $13.8 \mathrm{a}$ & $39.4 b$ & $206 c$ & $2.324 b$ & 0.398 & 18.4 \\
\hline $\mathrm{S}+\mathrm{I}$ & 6.06 & 0.054 & 41.7 & 3.59 & 5.78 & $11.6 b$ & $37.3 b$ & $329 \mathrm{a}$ & $2.523 \mathrm{a}$ & 0.383 & 18.9 \\
\hline NS & ns & ns & ns & ns & ns & ns & ns & $* *$ & $*$ & ns & ns \\
\hline MI & ns & ns & ns & ns & ns & ns & $*$ & $* *$ & $\mathrm{~ns}$ & ns & $\mathrm{ns}$ \\
\hline $\mathrm{S} \times \mathrm{M}$ & ns & ns & ns & ns & ns & $*$ & ns & $*$ & ns & ns & ns \\
\hline
\end{tabular}

3.2 Yield and quality of fruit and photosynthetic activities

3.2.1 Positive effect NS application at low rate on plants in larger pots (Exp I)

Application with nitrate salts (NS) of $\mathrm{Ca}\left(\mathrm{NO}_{3}\right)_{2}$ and $\mathrm{KNO}_{3}$ in Exp I increased plant growth and fruit yield and also improved fruit quality by increasing glucose concentration (Table 2). Fruit yield improvement by NS application was attributed to the increase in fruit number rather than increased fruit size. NS application decreased photosynthetic capacity $\left(P_{\mathrm{C}}\right)$ but increased the maximum quantum yield $\left(Y_{\mathrm{Q}}\right)$. The effect of salt and can also be seen in the photosynthesis-light curves in Figure 1. The curve was much curvier in salt treatments than in the controls.

Table 2 Yield and quality of fruit and the photosynthesis activity parameters (Exp I)

\begin{tabular}{|c|c|c|c|c|c|c|c|}
\hline Treat & Yield/g $\cdot$ plant $^{-1}$ & Fruit number/F·plant ${ }^{-1}$ & Fruit size/g & Glucose $/ \mathrm{g} \cdot \mathrm{kg}^{-1}$ & $P_{\mathrm{C}} / \mu \mathrm{mol} \cdot \mathrm{m}^{-2} \cdot \mathrm{s}^{-1}$ & $R_{\mathrm{D}} / \mu \mathrm{mol} \cdot \mathrm{m}^{-2} \cdot \mathrm{s}^{-1}$ & $Y_{\mathrm{Q}} / \mathrm{mol} \cdot \mathrm{mol}^{-1}$ \\
\hline $\mathrm{CK}$ & $331 \mathrm{c}$ & $5.6 \mathrm{c}$ & $59.1 \mathrm{~b}$ & $12.1 \mathrm{c}$ & $22.1 b$ & $3.2 \mathrm{~b}$ & $0.0471 \mathrm{~b}$ \\
\hline NS & $383 b$ & $6.4 \mathrm{~b}$ & $59.9 \mathrm{~b}$ & $16.5 b$ & $20.2 \mathrm{c}$ & $3.7 \mathrm{a}$ & $0.0772 \mathrm{a}$ \\
\hline MI & $370 \mathrm{~b}$ & $6.1 b$ & $60.7 \mathrm{a}$ & $23.5 \mathrm{a}$ & $23.6 \mathrm{a}$ & $3.3 b$ & $0.0498 \mathrm{~b}$ \\
\hline S-MI & $453 \mathrm{a}$ & $7.3 \mathrm{a}$ & $62.1 \mathrm{a}$ & $24.7 \mathrm{a}$ & $18.6 \mathrm{~d}$ & $3.7 \mathrm{a}$ & $0.0787 \mathrm{a}$ \\
\hline $\mathrm{S}$ & $* *$ & $* *$ & ns & $*$ & $*$ & $*$ & $* *$ \\
\hline MI & $* *$ & * & $*$ & $* *$ & $*$ & ns & ns \\
\hline $\mathrm{S} \times \mathrm{M}$ & $*$ & * & ns & ns & $* *$ & ns & ns \\
\hline
\end{tabular}

Note: $P_{\mathrm{C}}$, photosynthetic capacity; $R_{\mathrm{D}}$, dark respiration rate; $Y_{\mathrm{Q}}$, quantum yield. 


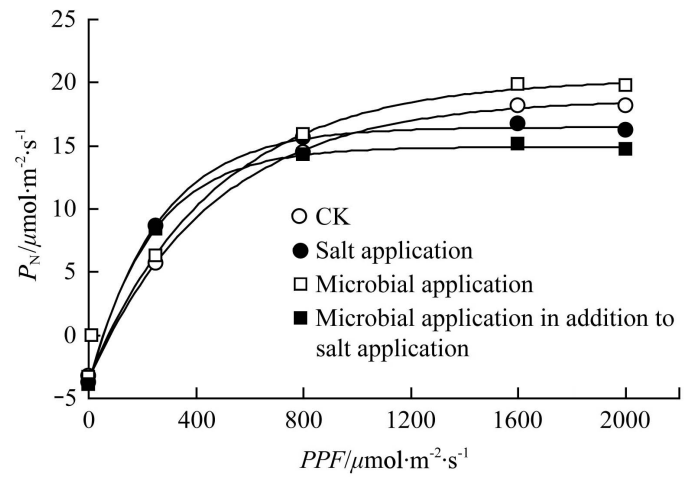

Figure 1 Photosynthesis-light response curve in leaves of tomato plants in different treatment plots in Exp I
3.2.2 Effect of NS application at low rate on plants in small pots (Exp II)

As shown in Table 3, application of NS in Exp II, where the small pot were used, could not result in positive effect on dry mass production as shown in Exp I although the application rate was the same. This might be due to the small soil volume that could not show enough soil buffer ability as in Exp I. Nevertheless, application of NS did not cause significant negative effect on dry mass production and photosynthetic activities.

3.2.3 Negative effect of $\mathrm{NaCl}$ application at low rate in small pots (Exp II)

At the same application rate as for NS, application of $\mathrm{NaCl}$ significantly decreased dry mass production and photosynthetic activities.

Table 3 Biomass production and photosynthetic activities in tomato plants grown in different conditions

\begin{tabular}{|c|c|c|c|c|c|c|c|c|c|c|c|c|c|}
\hline \multirow{2}{*}{ Plot } & \multicolumn{6}{|c|}{ Exp II } & \multicolumn{6}{|c|}{ Exp III } & \multirow{2}{*}{$\begin{array}{c}\text { Died } \\
\text { plant } / \%\end{array}$} \\
\hline & $\begin{array}{l}\text { Dry mass/ } \\
\mathrm{g} \cdot \text { plant }^{-1}\end{array}$ & $\mathrm{R} / \mathrm{T}$ & $\begin{array}{l}\text { Leaf } \\
\mathrm{A} / \mathrm{cm}^{2}\end{array}$ & $\begin{array}{c}P_{\mathrm{C}} / \\
\mathrm{g} \cdot \mathrm{kg}^{-1}\end{array}$ & $\begin{array}{c}R_{\mathrm{D}} / \\
\mu \mathrm{mol} \cdot \mathrm{m}^{-2} \cdot \mathrm{s}^{-1}\end{array}$ & $\begin{array}{c}Y_{\mathrm{Q}} / \\
\mathrm{mol} \cdot \mathrm{mol}^{-1}\end{array}$ & $\begin{array}{l}\text { Dry mass/ } \\
\mathrm{g} \cdot \text { plant }^{-1}\end{array}$ & $\mathrm{R} / \mathrm{T}$ & $\begin{array}{l}\text { Leaf } \\
\mathrm{A} / \mathrm{cm}^{2}\end{array}$ & $\begin{array}{c}P_{\mathrm{C}} / \\
\mathrm{g} \cdot \mathrm{kg}^{-1}\end{array}$ & $\begin{array}{c}R_{\mathrm{D}} / \\
\mu \mathrm{mol} \cdot \mathrm{m}^{-2} \cdot \mathrm{s}^{-1}\end{array}$ & $\begin{array}{c}Y_{\mathrm{Q}} / \\
\mathrm{mol} \cdot \mathrm{mol}^{-1}\end{array}$ & \\
\hline CK & $0.345 b$ & $0.180 \mathrm{~d}$ & $151 \mathrm{ab}$ & $13.1 \mathrm{a}$ & $1.71 \mathrm{~b}$ & $0.0301 \mathrm{c}$ & $0.332 b$ & 0.191 & $132 b$ & $11.7 \mathrm{a}$ & $0.96 \mathrm{c}$ & $0.0435 \mathrm{c}$ & $0.0 \mathrm{~d}$ \\
\hline NS & $0.339 \mathrm{c}$ & $0.197 \mathrm{c}$ & $144 b$ & $12.7 \mathrm{a}$ & $1.85 \mathrm{a}$ & $0.0334 b$ & $0.254 \mathrm{c}$ & 0.174 & $101 \mathrm{c}$ & $8.9 b$ & $1.47 \mathrm{a}$ & $0.0376 \mathrm{a}$ & $0.0 \mathrm{~d}$ \\
\hline $\mathrm{CS}$ & $0.186 f$ & $0.225 b$ & $101 \mathrm{c}$ & $10.3 \mathrm{c}$ & $1.43 \mathrm{~d}$ & $0.0261 \mathrm{~d}$ & $0.161 \mathrm{~d}$ & 0.196 & $92 d$ & $9.3 b$ & $1.11 \mathrm{~b}$ & $0.0252 \mathrm{c}$ & $46.7 \mathrm{~b}$ \\
\hline MI & $0.361 \mathrm{a}$ & $0.161 \mathrm{e}$ & $159 \mathrm{a}$ & $13.2 \mathrm{a}$ & $1.74 \mathrm{~b}$ & $0.0292 \mathrm{c}$ & $0.371 \mathrm{a}$ & 0.187 & $153 \mathrm{a}$ & $12.3 \mathrm{a}$ & $1.01 \mathrm{c}$ & $0.0355 \mathrm{~b}$ & $2.9 \mathrm{c}$ \\
\hline $\mathrm{MN}$ & $0.327 \mathrm{~d}$ & $0.219 b$ & $139 \mathrm{~b}$ & $13.4 \mathrm{a}$ & $1.81 \mathrm{a}$ & $0.0367 \mathrm{a}$ & $0.234 b$ & 0.182 & $93 c$ & $8.1 \mathrm{c}$ & $0.90 \mathrm{c}$ & $0.0249 \mathrm{c}$ & $6.7 \mathrm{c}$ \\
\hline $\mathrm{MC}$ & $0.203 \mathrm{e}$ & $0.276 \mathrm{a}$ & $94 \mathrm{c}$ & $11.2 \mathrm{~b}$ & $1.62 \mathrm{c}$ & $0.0295 \mathrm{c}$ & $0.131 \mathrm{e}$ & 0.189 & $61 \mathrm{e}$ & $7.2 \mathrm{~d}$ & $0.91 \mathrm{c}$ & $0.0228 \mathrm{c}$ & $60.2 \mathrm{a}$ \\
\hline $\mathrm{S}$ & $* *$ & $* *$ & $* *$ & $* *$ & $*$ & $*$ & $* *$ & ns & $* *$ & $* *$ & $* *$ & $* *$ & $* *$ \\
\hline MI & $*$ & $*$ & $*$ & $\mathrm{~ns}$ & ns & ns & $*$ & ns & $*$ & ns & ns & ns & ns \\
\hline $\mathrm{S} \times \mathrm{M}$ & $*$ & $*$ & $* *$ & $*$ & ns & $*$ & $*$ & ns & $* *$ & $*$ & ns & $*$ & $*$ \\
\hline
\end{tabular}

3.2.4 Negative effect of applications of $\mathrm{NS}$ and $\mathrm{NaCl}$ at high rate in small pots in small pots (Exp III)

As shown by the results of Exp II in Table 3, NS application at high rate significantly decreased biomass and photosynthetic activities. At this high rate, application of $\mathrm{NaCl}$ showed negative effects more severely on biomass production and photosynthetic activities more severely than NS did. $\mathrm{NaCl}$ application also caused plant death at a rate as high as $46.7 \%$.

3.2.5 Interaction of Microbial inoculant with $\mathrm{NS}$ or $\mathrm{NaCl}$ application on biomass production and photosynthetic activities (Exp I, II and III)

In Exp I, where the pot soil volume was larger, application of microbial inoculant (MI) increased fruit yield and improved fruit quality (Table 2). Fruit yield improvement by MI application was attributed to increased fruit size, while that by NS application was attributed to the increase in fruit number. There existed synergistic interaction between NS and MI applications on fruit yield. Photosynthetic capacity $\left(P_{\mathrm{C}}\right)$ was increased by applying MI although it was decreased by NS applications. MI application did not alleviate the photosynthetic depression caused by NS applications rather further depressed $P_{\mathrm{C}}$ in addition to NS application. In Exp II, MI application showed slight positive effect on biomass production but not on photosynthetic activities. IM application also showed a slight effect in alleviation of damage by $\mathrm{NaCl}$ application in both biomass production and photosynthetic activities. In Exp III, where the application rate of both NS and CS was doubled, MI application showed negative interaction with both NS and CS, aggravating instead of alleviating the damages.

3.3 Plant water relations and turgor maintenance at water-saturated status

3.3.1 Effects of NS and MI at low rate in large pots (Exp I)

Leaf water potential $\left(\Psi_{\mathrm{FT}}\right)$, osmotic potential $\left(\pi_{\mathrm{FT}}\right)$ and turgor potential $\left(P_{\mathrm{FT}}\right)$ indicated plant water relations without water stress when soil salinity was released. Both $\Psi_{\mathrm{FT}}$ and $\pi_{\mathrm{FT}}$ were lowered by NS application but $\pi_{\mathrm{FT}}$ was decreased more than $\Psi_{\mathrm{FT}}$ (Table 4). Therefore, $P_{\mathrm{FT}}$ was higher in plants with NS treatments because of $P_{\mathrm{FT}}=\Psi_{\mathrm{FT}}-\pi_{\mathrm{FT}}$. This suggested that leaf turgor potential would be improved if the salinity was released after a period of treatment. Similarly, both leaf water potential at midday $\left(\Psi_{\mathrm{MD}}\right)$ and osmotic potential at midday $\left(\pi_{\mathrm{MD}}\right)$ were lower in NS plots but $\pi_{\mathrm{MD}}$ was lowered more than $\Psi_{\mathrm{MD}}$ and consequently leaf turgor potential at midday $\left(P_{\mathrm{MD}}\right)$ was a little higher in NS plots. This suggested that leaf turgor potential would be improved if the application rate of NS was moderately low. Application of MI aggravated effecting in decreasing leaf water potential both at midday and after stress released but helped maintain leaf turgor potential (Table 4).

3.3.2 Effects of NS and MI at low rate in small pots (Exp II)

In Exp II, application of both NS and CS decreased leaf water potential at both turgid status and midday. Because of more lowering in $\Psi_{\mathrm{FT}}$ than in $\pi_{\mathrm{FT}}, P_{\mathrm{FT}}$ was higher in both NS and CS plots. However, at midday, because of more lowering in $\Psi_{\mathrm{MD}}$ than in $\pi_{\mathrm{MD}}, P_{\mathrm{MD}}$ was lower in NS and CS plots. The positive effect of NS was larger than that of CS in maintenance of turgor potential. MI showed no direct effect on leaf water relations but showed interaction with both NS and CS in aggravating the salinity effect, causing further lower in $P_{\mathrm{MD}}$.

3.3.3 Effects of NS and MI at high rate in small pots (Exp III)

In Exp III, where the application rate of both NS and CS was doubled, NS and CS significantly decreased leaf water potential at both turgid status and midday (Table 3). Because the salinity caused by both NS and CS could not induce further lowering in leaf osmotic potential, leaf turgor potential was lowered and reached zero at midday, causing plant death as shown in Table 3. MI showed aggravating effect on the salinity damage in aspects of leaf water relations. 
Table 4 Variables from analysis of osmotic adjustment (Exp I)

\begin{tabular}{|c|c|c|c|c|c|c|c|c|c|c|c|c|c|c|c|}
\hline & $\Psi_{\mathrm{FT}}$ & $\pi_{\mathrm{FT}}$ & $P_{\mathrm{FT}}$ & $\Psi_{\mathrm{MD}}$ & $\pi_{\mathrm{MD}}$ & $P_{\mathrm{MD}}$ & $\pi_{\mathrm{s}+\mathrm{a}}$ & $\pi_{\mathrm{IP}}$ & $\zeta_{\mathrm{IP}}$ & $\zeta_{\text {apo }}$ & $\zeta_{\text {sym }}$ & \multirow{2}{*}{$\alpha$} & \multirow{2}{*}{$\beta$} & $C_{\mathrm{osm}}$ & $\Delta C_{\mathrm{osm}}$ \\
\hline IItat & & & \multicolumn{5}{|c|}{$\mathrm{MPa}$} & \multicolumn{4}{|c|}{$\%$} & & & \multicolumn{2}{|c|}{ osmol m $\mathrm{m}^{-3}$} \\
\hline CK & $-0.217 \mathrm{a}$ & $-0.90 \mathrm{a}$ & $0.68 b$ & $-0.712 \mathrm{a}$ & $-0.915 \mathrm{a}$ & $0.203 \mathrm{~d}$ & $-0.68 \mathrm{a}$ & $-1.162 \mathrm{a}$ & $0.883 \mathrm{a}$ & $0.237 \mathrm{a}$ & $0.763 b$ & $51.4 \mathrm{a}$ & $0.981 \mathrm{a}$ & $369.2 \mathrm{~d}$ & $0.0 \mathrm{~d}$ \\
\hline NS & $-0.232 b$ & $-1.01 \mathrm{~b}$ & $0.78 \mathrm{a}$ & $-0.757 b$ & $-1.041 b$ & $0.284 b$ & $-0.82 b c$ & $-1.251 b$ & $0.859 \mathrm{~b}$ & $0.185 b$ & $0.815 a$ & $29.9 \mathrm{c}$ & $0.919 b$ & $412.8 b$ & $43.7 b$ \\
\hline MI & $-0.225 b$ & $-0.94 a$ & $0.71 b$ & $-0.702 \mathrm{a}$ & $-0.918 \mathrm{a}$ & $0.216 \mathrm{c}$ & $-0.78 b$ & $-1.193 \mathrm{a}$ & $0.795 \mathrm{c}$ & $0.218 \mathrm{a}$ & $0.782 b$ & $43.7 b$ & $0.922 b$ & $395.8 \mathrm{c}$ & $16.4 \mathrm{c}$ \\
\hline $\mathrm{MN}$ & $-0.267 \mathrm{c}$ & $-1.06 \mathrm{c}$ & $0.79 a$ & $-0.793 \mathrm{c}$ & $-1.112 \mathrm{c}$ & $0.319 \mathrm{a}$ & $-0.87 \mathrm{c}$ & $-1.486 \mathrm{c}$ & $0.849 \mathrm{~b}$ & $0.178 b$ & $0.828 \mathrm{a}$ & $26.0 \mathrm{c}$ & $0.907 \mathrm{c}$ & $432.5 \mathrm{a}$ & $63.3 \mathrm{a}$ \\
\hline S & $*$ & $* *$ & * & $*$ & * & $*$ & $* *$ & $*$ & $*$ & $* *$ & $* *$ & $* *$ & $*$ & $* *$ & $* *$ \\
\hline MI & $*$ & $*$ & $*$ & ns & ns & $*$ & $*$ & ns & $*$ & ns & ns & $*$ & $*$ & $*$ & $*$ \\
\hline $\mathrm{S} \times \mathrm{M}$ & $*$ & $*$ & ns & $*$ & $*$ & $* *$ & $*$ & $* *$ & ns & $*$ & $*$ & $*$ & $*$ & $*$ & $*$ \\
\hline
\end{tabular}

Note: $\Psi_{\mathrm{FT}}, \pi_{\mathrm{FT}}$ and $P_{\mathrm{FT}}$ were leaf water potential $(\Psi)$, osmotic potential $(\pi)$ and turgor potential $(P)$ at full turgid status. $\pi_{\mathrm{s}+\mathrm{a}}$ was $\pi$ when symplastic solution was diluted by apoplastic solution. $\pi_{\mathrm{IP}}$ was $\pi$ at incipient plasmolysis. $\zeta_{\mathrm{IP}}$ was the relative leaf water content $(\zeta)$ at incipient plasmolysis. $\zeta_{\text {apo }}$ and $\zeta_{\text {sym }}$ was $\zeta$ in fractions of apoplasm and symplasm. The coefficients $\alpha$ and $\beta$ were related with the curvature of first steep part and the second sloping part in the P-V curve. $C_{\text {osm }}$ was the osmotic concentration and $\Delta C_{\text {osm }}$ was the active increase in $C_{\text {osm }}$ due to the osmotic adjustment.

\subsection{Osmotic adjustment}

3.4.1 Effects of NS and MI at low rate in large pots (Exp I)

The ability of osmotic adjustment can be shown by the active increase in solute concentration. In Exp I, with the control plot $(\mathrm{CK})$ as the zero reference $\left(\Delta C_{\mathrm{osm}}=0\right)$, osmotic concentration at fully turgid status $\left(\Delta C_{\mathrm{osm}}\right)$ was 43.9 and $63.3 \mathrm{osmol} / \mathrm{m}^{3}$ in leaves of NS treatments with and without MI application, respectively (Table 4). The results suggested that osmotic adjustment really occurred when NS was applied at a moderately low rate. The osmotic adjustment caused by MI application was small with an additive interaction between NS and MI applications.

3.4.2 Effects of NS and MI at low rate in small pots (Exp II)
Application of both NS and CS induced additional active solute accumulation but this positive effect by NS was larger than that by CS (Table 5). MI showed no effect on additional active solute accumulation but showed synergistic interaction with NS and CS. 3.4.3 Effects of NS and MI at high rate in small pots (Exp III)

In Exp III (Table 6), where the application rate of NS and SC was doubled, application of NS showed a little effect in increasing solutes but this positive effect was much smaller than in Exp I and Exp II. Different from results in Exp I and Exp II, application of CS did not induce additional active accumulation of solutes. MI showed no direct effect on active solute accumulation neither the interaction effect with NS and CS.

Table 5 Variables from analysis of osmotic adjustment (Exp II)

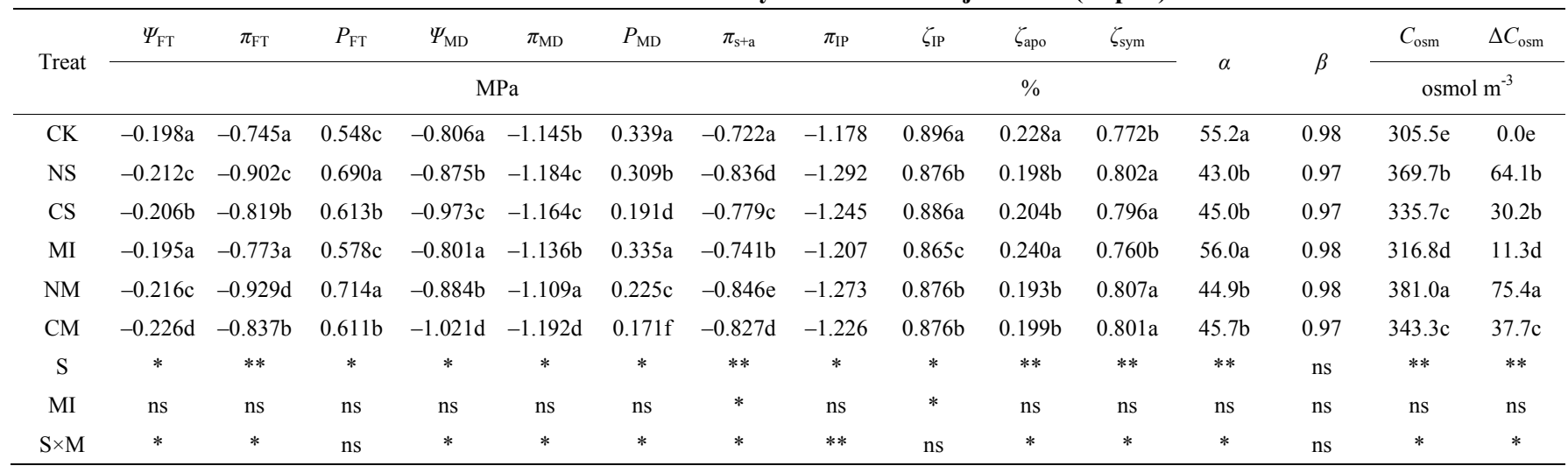

Table 6 Variables from analysis of osmotic adjustment (Exp III)

\begin{tabular}{|c|c|c|c|c|c|c|c|c|c|c|c|c|c|c|c|}
\hline & $\Psi_{\mathrm{FT}}$ & $\pi_{\mathrm{FT}}$ & $P_{\mathrm{FT}}$ & $\Psi_{\mathrm{MD}}$ & $\pi_{\mathrm{MD}}$ & $P_{\mathrm{MD}}$ & $\pi_{\mathrm{s}+\mathrm{a}}$ & $\pi_{\mathrm{IP}}$ & $\zeta_{\mathrm{IP}}$ & $\zeta_{\text {apo }}$ & $\zeta_{\text {sym }}$ & \multirow{2}{*}{$\alpha$} & \multirow{2}{*}{$\beta$} & $C_{\mathrm{osm}}$ & $\Delta C_{\mathrm{osm}}$ \\
\hline & & & \multicolumn{5}{|c|}{$\mathrm{MPa}$} & \multicolumn{4}{|c|}{$\%$} & & & \multicolumn{2}{|c|}{ osmol m${ }^{-3}$} \\
\hline $\mathrm{CK}$ & $-0.203 a$ & $-0.792 a$ & $0.589 \mathrm{a}$ & $-0.862 \mathrm{a}$ & -1.126 & $0.264 \mathrm{a}$ & $-0.743 \mathrm{a}$ & -1.193 & 0.861 & $0.263 \mathrm{a}$ & $0.737 \mathrm{c}$ & $57.2 \mathrm{a}$ & 0.97 & $324.7 \mathrm{~b}$ & $0.0 \mathrm{~b}$ \\
\hline NS & $-0.285 b$ & $-0.862 b$ & $0.577 b$ & $-1.075 b$ & -1.107 & $0.032 b$ & $-0.796 b$ & -1.216 & 0.855 & $0.229 \mathrm{c}$ & $0.771 \mathrm{a}$ & $46.0 \mathrm{~b}$ & 0.98 & $353.4 \mathrm{a}$ & $28.7 \mathrm{a}$ \\
\hline $\mathrm{CS}$ & $-0.265 c$ & $-0.798 \mathrm{a}$ & $0.533 \mathrm{c}$ & $-1.179 b$ & -1.176 & $0.000 \mathrm{~b}$ & $-0.792 b$ & -1.234 & 0.858 & $0.244 b$ & $0.756 \mathrm{~b}$ & $48.0 \mathrm{~b}$ & 0.97 & $327.2 \mathrm{~b}$ & $2.5 b$ \\
\hline MI & $-0.201 \mathrm{a}$ & $-0.796 a$ & $0.595 \mathrm{a}$ & $-0.881 \mathrm{a}$ & -1.127 & $0.246 \mathrm{a}$ & $-0.763 \mathrm{a}$ & -1.187 & 0.852 & $0.254 \mathrm{a}$ & $0.746 \mathrm{c}$ & $56.3 \mathrm{a}$ & 0.97 & $326.4 \mathrm{~b}$ & $1.6 \mathrm{~b}$ \\
\hline NM & $-0.297 \mathrm{a}$ & $-0.809 \mathrm{a}$ & $0.512 \mathrm{c}$ & $-1.164 b$ & -1.009 & $0.000 \mathrm{~b}$ & $-0.855 \mathrm{c}$ & -1.203 & 0.854 & $0.226 \mathrm{c}$ & $0.774 \mathrm{a}$ & $46.8 b$ & 0.98 & $331.7 \mathrm{~b}$ & $7.0 \mathrm{~b}$ \\
\hline $\mathrm{CM}$ & $-0.286 b$ & $-0.802 \mathrm{a}$ & $0.516 \mathrm{c}$ & $-1.176 b$ & -1.162 & $0.000 \mathrm{~b}$ & $-0.866 \mathrm{c}$ & -1.207 & 0.857 & $0.249 b$ & $0.751 \mathrm{~b}$ & $47.2 \mathrm{~b}$ & 0.97 & $328.8 \mathrm{~b}$ & $4.1 \mathrm{~b}$ \\
\hline $\mathrm{S}$ & $*$ & $*$ & $*$ & $*$ & $\mathrm{~ns}$ & $*$ & $* *$ & ns & $\mathrm{ns}$ & $*$ & * & $*$ & ns & $*$ & $*$ \\
\hline MI & ns & ns & ns & ns & ns & ns & $\mathrm{ns}$ & ns & ns & ns & ns & $\mathrm{ns}$ & ns & ns & ns \\
\hline $\mathrm{S} \times \mathrm{M}$ & $*$ & ns & $*$ & $*$ & ns & $*$ & $*$ & ns & $\mathrm{ns}$ & ns & ns & ns & $\mathrm{ns}$ & ns & $\mathrm{ns}$ \\
\hline
\end{tabular}

3.5 Water stress tolerance shown by osmotic potential and relative water content at incipient plasmolysis

3.5.1 Effects of NS and MI at low rate in large pots (Exp I)

Water stress tolerance can be shown as one of the indicators by osmotic potential $\left(\pi_{\mathrm{IP}}\right)$ or relative water content $\left(\zeta_{\mathrm{IP}}\right)$ at incipient plasmolysis, when the cell membrane is just separated from the cell wall or when the leaf turgor potential is zero. In Exp I, where the application rate of NS was low and the pots were large, $\pi_{\mathrm{IP}}$ was lowered by NS application although $\zeta_{\text {IP }}$ was not (Table 4). This suggested that a leaf in NS treatment could maintain its turgor to a 
more severe water stress level in comparison with its control plots. MI application did not show this kind of effect but showed an additive or synergistic interaction with NS treatment.

3.5.2 Effects of NS and MI at low rate in small pots (Exp II)

In Exp II, where the pots were smaller than in Exp I, application of NS lowered both $\pi_{\mathrm{IP}}$ and $\zeta_{\mathrm{IP}}$. CS also lowered $\pi_{\mathrm{IP}}$ but $\zeta_{\mathrm{IP}}$. Although the positive effect of NS and CS was lower than in Exp I, the improvement in water stress tolerance by NS and CS application was confirmed. MI showed no significant direct effect on $\pi_{\mathrm{IP}}$ but significant on $\zeta_{\mathrm{IP}}$, with significant negative interaction on $\pi_{\mathrm{IP}}$ with NS and CS.

3.5.3 Effects of NS and MI at high rate in small pots (Exp III)

In Exp III, where the application rate was doubled and severe salinity damages were induced, application of both NS and CS did not show any effect on $\pi_{\mathrm{IP}}$ and $\zeta_{\mathrm{IP}}$.

\subsection{Cell water re-compartmentation}

3.6.1 Effects of NS and MI at low rate in large pots (Exp I)

Usually, water in a cell of tomato leaf is compartmented $0.76 \%$ in the symplasm, called symplastic water fraction $\left(\zeta_{\text {sym }}\right)$, and $24 \%$ in cell wall or apoplasm, called the apoplast water fraction $\left(\zeta_{\text {sym }}\right)$, as shown in the control plot of Exp I (Table 4). When the plant meets water or salinity stress, water in cell wall or the apoplasm may moves into the symplasm. Thus, water fraction would increase in symplasm and decrease in apoplasm, no matter the change in absolute value of the total cell water content was large or small. In Exp I, $\zeta_{\text {sym }}$ was increased and the apoplast water fraction $\left(\zeta_{\text {sym }}\right)$ decreased by NS application. MI application did not change the cell water fraction but showed a synergistic interaction with NS treatment.

3.6.2 Effects of NS and MI at low rate in small pots (Exp II)

In Exp II, NS application increased symplastic water fraction more than CS did. MI application did not significantly affect the cell water compartmentation but showed a synergistic interaction with NS and CS.

3.6.3 Effects of NS and MI at high rate in small pots (Exp III)

In Exp III, NS application increased cell symplastic water fraction but CS did not reach the significant levels. MI did not show effect on cell water compartmentation and showed neither interaction with NS or CS.

3.7 Nitrate content, nitrate reductase and the expression of nitrate reductase gene

3.7.1 Effects of NS and MI at low rate in large pots (Exp I)

The total leaf nitrogen content was increased by NS application and this was proportional to leaf color at both early and late stages. MI application did not increase the total nitrogen content and leaf color but showed a synergistic interaction with NS treatment (Table 7). Leaf nitrate concentration was not higher or even lower in NS treatments than the controls and this was not consistent with the total leaf nitrogen content. The lower nitrate concentration might be attributed to the higher activity of nitrate reductase in NS treatments than in the controls. MI application did not show much effect on nitrate concentration and the activity of nitrate reductase. The relative expression of NR gene was higher in NS treatments and this was consistent with the nitrate reductase activity. MI application also showed a promoting effect on NR gene expression with additive or synergistic interaction between NS and MI applications.

3.7.2 Effects of NS and MI at low rate in small pots (Exp II)

In Exp II, NS application increased leaf total $\mathrm{N}$ and nitrate contents but CS decreased N (Table 8). MI did not show any effect on leaf total $\mathrm{N}$ and nitrate content. Leaf color showed a consistent changing trend with the leaf $\mathrm{N}$ status. NS increased nitrate reductase (NR) activity but CS decreased NR activity. MI increased NR activity and showed a positive interaction with NS and CS. NS application induced up-regulation expression of NRI gene but did not show this effect. MI did not affect the NRI expression but showed a significant positive interaction with NS and CS.

3.7.3 Effects of NS and MI at high rate in small pots (Exp III)

In Exp III, NS increased but CS decreased the total leaf $\mathrm{N}$ and nitrate $\mathrm{N}$ content and MI did not affect leaf nitrogen (Table 9). Leaf color reflected the leaf $\mathrm{N}$ status. NS induced up-regulation of NRI gene and increased NR activity. CS did not show this effect and MI also showed no this effect.

Table 7 Nitrogen contents, nitrate reductase activity and relative expression of NR gene in tomato leaves in different plots (Exp I)

\begin{tabular}{|c|c|c|c|c|c|c|c|c|c|}
\hline \multirow{2}{*}{ Plot } & \multirow{2}{*}{$\begin{array}{c}\text { Total N } \\
/ \mathrm{g} \mathrm{kg}^{-1} \mathrm{DM}\end{array}$} & \multirow{2}{*}{$\begin{array}{c}\text { Nitrate } \\
/ \mathrm{g} \mathrm{kg}^{-1} \mathrm{FM}\end{array}$} & \multirow{2}{*}{ Leaf color } & \multicolumn{3}{|c|}{$\mathrm{NR}$ activity $/ \mathrm{mg} \mathrm{kg}^{-1} \cdot \mathrm{h}^{-1}$} & \multicolumn{3}{|c|}{$N R 1$ expression } \\
\hline & & & & $1 \mathrm{~d}$ & $7 \mathrm{~d}$ & $35 \mathrm{~d}$ & $1 \mathrm{~d}$ & $7 \mathrm{~d}$ & $35 \mathrm{~d}$ \\
\hline $\mathrm{CK}$ & $14.7 \mathrm{~b}$ & $1.03 \mathrm{~b}$ & $38.4 \mathrm{c}$ & $0.77 \mathrm{ab}$ & $0.12 \mathrm{c}$ & $0.59 \mathrm{~d}$ & $0.81 \mathrm{c}$ & $2.01 \mathrm{c}$ & $3.34 \mathrm{c}$ \\
\hline NS & $15.7 \mathrm{a}$ & $1.21 \mathrm{a}$ & $48.2 \mathrm{a}$ & $0.79 \mathrm{ab}$ & $1.58 \mathrm{a}$ & $1.58 \mathrm{~b}$ & $1.34 \mathrm{~b}$ & $4.704 \mathrm{~b}$ & $6.06 \mathrm{~b}$ \\
\hline MI & $15.0 \mathrm{~b}$ & $1.12 \mathrm{ab}$ & $37.0 \mathrm{c}$ & $0.69 \mathrm{~b}$ & $0.29 \mathrm{c}$ & $1.02 \mathrm{c}$ & $1.47 \mathrm{~b}$ & $2.11 \mathrm{c}$ & $7.59 b$ \\
\hline MNI & $15.5 \mathrm{a}$ & $0.74 \mathrm{c}$ & $43.5 b$ & $0.85 \mathrm{a}$ & $1.17 \mathrm{~b}$ & $2.31 \mathrm{c}$ & $6.07 \mathrm{a}$ & $8.79 \mathrm{a}$ & $12.33 \mathrm{a}$ \\
\hline $\mathrm{S}$ & $*$ & $*$ & $* *$ & $\mathrm{~ns}$ & $* *$ & $* *$ & $* *$ & $* *$ & $* *$ \\
\hline MI & $*$ & $*$ & ns & ns & ns & $*$ & $* *$ & ns & $* *$ \\
\hline $\mathrm{S} \times \mathrm{M}$ & $*$ & $* *$ & $*$ & $*$ & $\mathrm{~ns}$ & $*$ & $* *$ & $* *$ & $*$ \\
\hline
\end{tabular}

Table 8 Nitrogen contents, nitrate reductase activity and relative expression of NR gene in tomato leaves in different plots (Exp II)

\begin{tabular}{|c|c|c|c|c|c|c|c|c|c|}
\hline \multirow{2}{*}{ Plot } & \multirow{2}{*}{$\begin{array}{c}\text { Total N } \\
/ \mathrm{g} \cdot \mathrm{kg}^{-1} \mathrm{DM}\end{array}$} & \multirow{2}{*}{$\begin{array}{c}\text { Nitrate } \\
/ \mathrm{g} \cdot \mathrm{kg}^{-1} \mathrm{FM}\end{array}$} & \multirow{2}{*}{ Leaf color } & \multicolumn{3}{|c|}{$\mathrm{NR}$ activity $/ \mathrm{mg} \cdot \mathrm{kg}^{-1} \cdot \mathrm{h}^{-1}$} & \multicolumn{3}{|c|}{$N R 1$ expression } \\
\hline & & & & $3 \mathrm{~d}$ & $8 \mathrm{~d}$ & $15 \mathrm{~d}$ & $3 \mathrm{~d}$ & $8 \mathrm{~d}$ & $15 \mathrm{~d}$ \\
\hline $\mathrm{CK}$ & $13.2 \mathrm{~b}$ & $1.14 \mathrm{~b}$ & $34.1 \mathrm{bc}$ & $1.48 \mathrm{~d}$ & $0.90 \mathrm{c}$ & $0.60 \mathrm{~d}$ & $1.00 \mathrm{c}$ & $2.18 \mathrm{c}$ & $3.70 \mathrm{c}$ \\
\hline NS & $14.4 \mathrm{a}$ & $1.33 \mathrm{a}$ & $35.3 b$ & $1.95 \mathrm{~b}$ & $1.55 \mathrm{~b}$ & $2.38 \mathrm{a}$ & $15.50 \mathrm{~b}$ & $11.40 \mathrm{~b}$ & $6.06 \mathrm{~b}$ \\
\hline $\mathrm{CS}$ & $12.1 \mathrm{c}$ & $1.01 \mathrm{c}$ & $33.6 \mathrm{c}$ & $1.39 \mathrm{~d}$ & $0.80 \mathrm{c}$ & $1.22 \mathrm{~b}$ & $1.22 \mathrm{c}$ & $2.71 \mathrm{c}$ & $4.59 \mathrm{c}$ \\
\hline MI & $13.4 \mathrm{~b}$ & $1.17 \mathrm{~b}$ & $35.0 \mathrm{~b}$ & $2.04 \mathrm{~b}$ & $0.79 \mathrm{c}$ & $1.46 \mathrm{~b}$ & $5.76 \mathrm{c}$ & $3.07 \mathrm{c}$ & $4.33 \mathrm{c}$ \\
\hline $\mathrm{MC}$ & $11.8 \mathrm{c}$ & $1.09 \mathrm{c}$ & $34.4 \mathrm{~b}$ & $1.71 \mathrm{c}$ & $1.79 \mathrm{~b}$ & $1.62 \mathrm{~b}$ & $2.36 \mathrm{c}$ & $2.96 \mathrm{c}$ & $2.39 \mathrm{c}$ \\
\hline $\mathrm{S}$ & $*$ & $*$ & $*$ & $*$ & $* *$ & $* *$ & $* *$ & $* *$ & $* *$ \\
\hline MI & $\mathrm{ns}$ & $\mathrm{ns}$ & ns & $*$ & $\mathrm{~ns}$ & $*$ & ns & ns & ns \\
\hline $\mathrm{S} \times \mathrm{M}$ & $*$ & $*$ & $*$ & $*$ & $*$ & $\mathrm{~ns}$ & $* *$ & $* *$ & $*$ \\
\hline
\end{tabular}


Table 9 Nitrogen contents, nitrate reductase activity and relative expression of NR gene in tomato leaves in different plots (Exp III)

\begin{tabular}{|c|c|c|c|c|c|c|c|c|c|}
\hline \multirow{2}{*}{ Plot } & \multirow{2}{*}{$\begin{array}{c}\text { Total N } \\
/ \mathrm{g} \mathrm{kg}^{-1} \mathrm{DM}\end{array}$} & \multirow{2}{*}{$\begin{array}{l}\text { Nitrate } \\
/ \mathrm{g} \mathrm{kg}^{-1} \mathrm{FM}\end{array}$} & \multirow{2}{*}{ Leaf color } & \multicolumn{3}{|c|}{$\mathrm{NR}$ activity $/ \mathrm{mg} \cdot \mathrm{kg}^{-1} \cdot \mathrm{h}^{-1}$} & \multicolumn{3}{|c|}{$N R 1$ expression } \\
\hline & & & & $6 \mathrm{~d}$ & $7 \mathrm{~d}$ & $31 \mathrm{~d}$ & $6 \mathrm{~d}$ & $7 \mathrm{~d}$ & $31 \mathrm{~d}$ \\
\hline CK & $12.2 b$ & $0.93 \mathrm{c}$ & $31.6 \mathrm{a}$ & $1.39 \mathrm{a}$ & $1.45 \mathrm{~b}$ & $0.98 \mathrm{~b}$ & $1.02 \mathrm{~b}$ & $0.98 \mathrm{c}$ & $1.03 \mathrm{c}$ \\
\hline NS & $13.7 \mathrm{a}$ & $1.12 \mathrm{a}$ & $36.5 \mathrm{a}$ & $1.72 \mathrm{a}$ & $2.25 \mathrm{a}$ & $1.92 \mathrm{a}$ & $1.27 \mathrm{a}$ & $1.90 \mathrm{~b}$ & $2.19 b$ \\
\hline $\mathrm{CS}$ & $10.9 \mathrm{c}$ & $0.84 d$ & $25.9 b$ & $1.58 \mathrm{a}$ & $1.65 \mathrm{~b}$ & $0.99 \mathrm{~b}$ & $0.87 \mathrm{c}$ & $0.92 \mathrm{c}$ & $0.85 \mathrm{c}$ \\
\hline MI & $12.5 \mathrm{~b}$ & $0.97 \mathrm{c}$ & $33.7 \mathrm{a}$ & $1.45 \mathrm{a}$ & $1.64 \mathrm{~b}$ & $1.18 \mathrm{~b}$ & $0.87 \mathrm{c}$ & $0.93 \mathrm{c}$ & $1.02 \mathrm{c}$ \\
\hline $\mathrm{MN}$ & $14.1 \mathrm{a}$ & $1.09 \mathrm{~b}$ & $37.5 \mathrm{a}$ & $0.95 b$ & $1.03 \mathrm{c}$ & $0.87 \mathrm{~b}$ & $1.49 \mathrm{a}$ & $2.72 \mathrm{a}$ & $3.26 \mathrm{a}$ \\
\hline $\mathrm{MC}$ & $10.2 \mathrm{c}$ & $0.79 \mathrm{~d}$ & $28.4 \mathrm{~b}$ & $0.88 \mathrm{~b}$ & $0.69 \mathrm{~d}$ & $0.54 \mathrm{c}$ & $0.92 \mathrm{c}$ & $1.02 \mathrm{c}$ & $0.96 \mathrm{c}$ \\
\hline $\mathrm{S}$ & $*$ & $*$ & $*$ & $*$ & $* *$ & $* *$ & $* *$ & $* *$ & $* *$ \\
\hline MI & ns & ns & ns & $*$ & ns & $*$ & ns & ns & ns \\
\hline $\mathrm{S} \times \mathrm{M}$ & $*$ & $*$ & $*$ & $*$ & $*$ & ns & $* *$ & $* *$ & $*$ \\
\hline
\end{tabular}

\subsection{Antioxidation activity}

3.8.1 Effects of NS and MI at low rate in large pots (Exp I)

NS application increased $\mathrm{O}_{2}^{-}$concentration in tomato leaves at the time of one day after treatments started (Table 10). However, at this time, NS application had not induced the activation of SOD, which responded to breakdown the stress-induced $\mathrm{O}_{2}^{-}$. Therefore, the concentration of MDA increased, which suggested that the cell membrane was damaged by the salinity stress. This was consistent with the midday wilting of the tomato that was observed in situ several hours after NS was applied. However, one week after treatments started, both $\mathrm{O}_{2}{ }^{-}$and MDA in tomato leaves in NS plot showed similar levels to those in control plot but the activity of SOD got higher than in control plots, especially in the plot of NS plus MI. This suggested that tomato plants acclimated to NS salinity by increasing SOD activity. MI application induced activation of SOD one day after treatment started and therefore there was no increase in $\mathrm{O}_{2}{ }^{-}$and MDA at this time and 7 days later. Because there was no $\mathrm{O}_{2}{ }^{-}$increase caused by $\mathrm{MI}$ application from the beginning, there was no more activation of SOD 7 days after treatments started. However, MI application showed high synergistic interaction with NS application.
3.8.2 Effects of NS and MI at low rate in small pots (Exp II)

In Exp II, NS application did not induce $\mathrm{O}_{2}^{-}$increase but did 8 days after treatment started and CS showed this effect from Day 3 (Table 11). Both NS and CS increased MDA concentration. NS and CS both induced up-regulation expression of the stress-response gene (DREB2) and increased SOD activity through the whole treatment period. MI application showed no effect on the gene expression, SOD activity and concentration of both $\mathrm{O}_{2}{ }^{-}$ and MDA but MI showed interactions with NS and CS on cases.

3.8.3 Effects of NS and MI at high rate in small pots (Exp III)

In Exp III, where application rate of NS and CS was doubled, both NS and CS increased $\mathrm{O}_{2}{ }^{-}$concentration immediately after treatments started and the high concentration of $\mathrm{O}_{2}^{-}$maintained through the whole experimental period but lowered down at the end for CS treatment (Table 12). MI showed no direct effect on $\mathrm{O}_{2}^{-}$ concentration but synergistically interacted with NS and CS. MDA concentration did not show clear changing trends affected by NS, CS and MI. Both NS and CS decreased SOD activity although they did induce up-regulation expression of NRI gene. MI also showed no clear effect on SOD but showed interactive effect with NS and CS on NRI expression.

Table 10 SOD activity and concentrations of $\mathrm{O}_{2}^{-}$and MDA as well as the relative expression of the stress-responsive gene of $D R E B 2$ (Exp I)

\begin{tabular}{|c|c|c|c|c|c|c|c|c|c|c|c|c|}
\hline \multirow{2}{*}{ Plot } & \multicolumn{3}{|c|}{$\mathrm{O}_{2}{ }^{-} / \mathrm{mmol} \cdot \mathrm{kg}^{-1} \mathrm{FM}$} & \multicolumn{3}{|c|}{$\mathrm{MDA} / \mathrm{mmol} \cdot \mathrm{kg}^{-1} \mathrm{FM}$} & \multicolumn{3}{|c|}{$\mathrm{SOD} / \mathrm{U} \cdot \mathrm{g}^{-1} \mathrm{FM}$} & \multicolumn{3}{|c|}{$D R E B 2$ expression } \\
\hline & $1 \mathrm{~d}$ & $7 \mathrm{~d}$ & $35 \mathrm{~d}$ & $1 \mathrm{~d}$ & $7 d$ & $35 \mathrm{~d}$ & $1 \mathrm{~d}$ & $7 \mathrm{~d}$ & $35 \mathrm{~d}$ & $1 \mathrm{~d}$ & $7 \mathrm{~d}$ & $35 \mathrm{~d}$ \\
\hline $\mathrm{CK}$ & $15.2 \mathrm{~d}$ & 16.8 & 13.2 & $1.01 \mathrm{~b}$ & 1.12 & 0.87 & $1980 \mathrm{~b}$ & $2040 c$ & $1324 \mathrm{c}$ & $1.07 \mathrm{c}$ & $1.06 \mathrm{~b}$ & $1.21 \mathrm{~b}$ \\
\hline NS & $37.2 \mathrm{~b}$ & 17.0 & 15.9 & $1.24 \mathrm{a}$ & 1.13 & 0.79 & $1740 \mathrm{~b}$ & $2760 \mathrm{~b}$ & $1763 b$ & $1.84 \mathrm{~b}$ & $3.74 \mathrm{a}$ & $7.37 \mathrm{a}$ \\
\hline MI & $29.1 \mathrm{c}$ & 14.6 & 16.1 & $0.97 b$ & 0.97 & 0.91 & $2280 \mathrm{a}$ & $2100 \mathrm{c}$ & $1401 \mathrm{c}$ & $1.01 \mathrm{c}$ & $1.23 \mathrm{~b}$ & $1.80 \mathrm{~b}$ \\
\hline $\mathrm{MN}$ & $47.8 \mathrm{a}$ & 17.3 & 16.4 & $1.26 \mathrm{a}$ & 1.15 & 1.01 & $2440 \mathrm{a}$ & $4904 a$ & $2352 a$ & $2.24 \mathrm{a}$ & $4.42 \mathrm{a}$ & $9.07 \mathrm{a}$ \\
\hline S & $* *$ & ns & ns & $*$ & ns & ns & ns & $* *$ & $*$ & $*$ & $*$ & $* *$ \\
\hline MI & $*$ & ns & ns & ns & $\mathrm{ns}$ & ns & ns & $\mathrm{ns}$ & ns & $\mathrm{ns}$ & ns & ns \\
\hline $\mathrm{S} \times \mathrm{M}$ & $*$ & ns & ns & ns & ns & ns & $*$ & $* *$ & $* *$ & $* *$ & $* *$ & $*$ \\
\hline
\end{tabular}

Table 11 SOD activity and concentrations of $\mathrm{O}_{2}^{-}$and MDA as well as the relative expression of the stress-responsive gene of $D R E B 2$ (Exp II)

\begin{tabular}{|c|c|c|c|c|c|c|c|c|c|c|c|c|}
\hline \multirow{2}{*}{ Plot } & \multicolumn{3}{|c|}{$\mathrm{O}_{2}{ }^{-} / \mathrm{mmol} \cdot \mathrm{kg}^{-1} \mathrm{FM}$} & \multicolumn{3}{|c|}{$\mathrm{MDA} / \mathrm{mmol} \cdot \mathrm{kg}^{-1} \mathrm{FM}$} & \multicolumn{3}{|c|}{$\mathrm{SOD} / \mathrm{U} \cdot \mathrm{g}^{-1} \mathrm{FM}$} & \multicolumn{3}{|c|}{$D R E B 2$ expression } \\
\hline & $3 \mathrm{~d}$ & $8 \mathrm{~d}$ & $15 \mathrm{~d}$ & $3 \mathrm{~d}$ & $8 \mathrm{~d}$ & $15 \mathrm{~d}$ & $3 \mathrm{~d}$ & $8 \mathrm{~d}$ & $15 \mathrm{~d}$ & $3 \mathrm{~d}$ & $8 \mathrm{~d}$ & $15 \mathrm{~d}$ \\
\hline CK & $3.27 \mathrm{~b}$ & $4.98 \mathrm{c}$ & $1.34 \mathrm{c}$ & $0.69 \mathrm{c}$ & $0.83 \mathrm{c}$ & $0.55 \mathrm{~d}$ & $402 d$ & $897 \mathrm{c}$ & $371 \mathrm{c}$ & $0.37 \mathrm{~d}$ & $1.01 \mathrm{~d}$ & $19.71 d$ \\
\hline NS & $3.02 \mathrm{~b}$ & $8.16 \mathrm{a}$ & $2.25 \mathrm{c}$ & $1.04 \mathrm{~b}$ & $1.35 \mathrm{~b}$ & $1.81 \mathrm{~b}$ & $521 \mathrm{c}$ & $990 \mathrm{c}$ & $527 \mathrm{~b}$ & $0.48 \mathrm{c}$ & $1.67 \mathrm{c}$ & $17.25 \mathrm{~d}$ \\
\hline $\mathrm{CS}$ & $5.59 \mathrm{a}$ & $10.4 \mathrm{a}$ & $8.76 \mathrm{a}$ & $1.42 \mathrm{a}$ & $2.34 \mathrm{a}$ & $2.31 \mathrm{a}$ & $742 b$ & $788 \mathrm{c}$ & $576 \mathrm{~b}$ & $0.61 \mathrm{~b}$ & $2.24 \mathrm{~b}$ & $34.80 \mathrm{~b}$ \\
\hline MI & $2.86 \mathrm{~b}$ & $4.90 \mathrm{c}$ & $3.39 \mathrm{c}$ & $0.90 \mathrm{bc}$ & $1.18 \mathrm{bc}$ & $0.66 \mathrm{~d}$ & $347 d$ & $742 \mathrm{c}$ & $346 c$ & $0.42 \mathrm{~cd}$ & $1.24 \mathrm{~cd}$ & $19.24 d$ \\
\hline $\mathrm{MN}$ & $3.87 \mathrm{~b}$ & $9.09 a$ & $5.94 \mathrm{~b}$ & $0.87 \mathrm{bc}$ & $2.07 \mathrm{a}$ & $1.08 \mathrm{c}$ & $765 b$ & $1787 \mathrm{a}$ & $776 a$ & $0.65 b$ & $2.01 \mathrm{~b}$ & $25.11 \mathrm{c}$ \\
\hline $\mathrm{MC}$ & $4.68 \mathrm{a}$ & $6.70 \mathrm{~b}$ & $6.10 \mathrm{~b}$ & $1.16 \mathrm{~b}$ & $1.86 \mathrm{a}$ & $1.41 \mathrm{~b}$ & $882 a$ & $1237 b$ & $812 a$ & $2.06 \mathrm{a}$ & $2.84 \mathrm{a}$ & $48.52 \mathrm{a}$ \\
\hline $\mathrm{S}$ & $* *$ & $* *$ & $* *$ & $*$ & $* *$ & $* *$ & $* *$ & ns & $*$ & $*$ & $* *$ & * \\
\hline MI & $\mathrm{ns}$ & $\mathrm{ns}$ & ns & $\mathrm{ns}$ & ns & ns & ns & $\mathrm{ns}$ & $\mathrm{ns}$ & ns & ns & ns \\
\hline $\mathrm{S} \times \mathrm{M}$ & $*$ & $* *$ & $*$ & ns & ns & ns & $*$ & $* *$ & $*$ & $*$ & ns & $* *$ \\
\hline
\end{tabular}


Table 12 SOD activity and concentrations of $\mathrm{O}_{2}^{-}$and MDA as well as the relative expression of the stress-responsive gene of $D R E B 2$ (Exp III)

\begin{tabular}{|c|c|c|c|c|c|c|c|c|c|c|c|c|}
\hline \multirow{2}{*}{ Plot } & \multicolumn{3}{|c|}{$\mathrm{O}_{2}{ }^{-} / \mathrm{mmol} \cdot \mathrm{kg}^{-1} \mathrm{FM}$} & \multicolumn{3}{|c|}{$\mathrm{MDA} / \mathrm{mmol} \cdot \mathrm{kg}^{-1} \mathrm{FM}$} & \multicolumn{3}{|c|}{$\mathrm{SOD} / \mathrm{U} \cdot \mathrm{g}^{-1} \mathrm{FM}$} & \multicolumn{3}{|c|}{$D R E B 2$ expression } \\
\hline & $6 \mathrm{~h}$ & $7 \mathrm{~d}$ & $31 \mathrm{~d}$ & $6 \mathrm{~h}$ & $7 \mathrm{~d}$ & $31 \mathrm{~d}$ & $6 \mathrm{~h}$ & $7 \mathrm{~d}$ & $31 \mathrm{~d}$ & $6 \mathrm{~h}$ & $7 d$ & $31 \mathrm{~d}$ \\
\hline CK & $2.16 \mathrm{c}$ & $6.32 \mathrm{c}$ & $5.52 \mathrm{~b}$ & 2.31 & $1.51 \mathrm{~d}$ & $1.19 \mathrm{c}$ & $946 a$ & $707 \mathrm{a}$ & $583 a$ & $1.00 \mathrm{c}$ & $1.00 \mathrm{~d}$ & $1.00 \mathrm{c}$ \\
\hline NS & $4.64 b$ & $8.24 \mathrm{~b}$ & $8.32 \mathrm{a}$ & 2.42 & $1.72 \mathrm{c}$ & $1.74 b$ & $749 b$ & $544 b$ & $473 b$ & $1.32 \mathrm{~b}$ & $1.69 \mathrm{~b}$ & $1.81 \mathrm{~b}$ \\
\hline $\mathrm{CS}$ & $4.88 \mathrm{~b}$ & $8.08 \mathrm{~b}$ & $4.24 \mathrm{~b}$ & 1.34 & $1.88 \mathrm{ab}$ & $0.79 d$ & $697 b$ & $435 \mathrm{c}$ & $366 \mathrm{c}$ & $1.21 \mathrm{~b}$ & $1.46 \mathrm{c}$ & $2.03 b$ \\
\hline MI & $2.64 \mathrm{c}$ & $7.40 \mathrm{bc}$ & $3.60 \mathrm{~b}$ & 1.91 & $1.61 \mathrm{~cd}$ & $1.71 \mathrm{~b}$ & $809 a$ & $595 b$ & $603 a$ & $0.97 \mathrm{c}$ & $1.07 \mathrm{~d}$ & $1.12 \mathrm{c}$ \\
\hline $\mathrm{MN}$ & $5.36 \mathrm{~b}$ & $11.04 \mathrm{a}$ & $9.36 \mathrm{a}$ & 2.77 & $1.78 \mathrm{~b}$ & $1.1 \mathrm{c}$ & $704 b$ & $453 c$ & $374 \mathrm{c}$ & $1.45 \mathrm{a}$ & $1.63 b$ & $2.72 \mathrm{a}$ \\
\hline $\mathrm{MC}$ & $7.92 \mathrm{a}$ & $10.32 \mathrm{a}$ & $5.52 \mathrm{~b}$ & 2.55 & $1.98 \mathrm{a}$ & $2.22 \mathrm{a}$ & $574 \mathrm{c}$ & $364 d$ & $366 \mathrm{c}$ & $1.63 \mathrm{a}$ & $1.94 \mathrm{a}$ & $2.96 \mathrm{a}$ \\
\hline $\mathrm{S}$ & $* *$ & $*$ & $*$ & ns & $*$ & $*$ & $*$ & $*$ & $*$ & $*$ & $*$ & $*$ \\
\hline MI & ns & ns & ns & ns & $\mathrm{ns}$ & ns & ns & ns & ns & $\mathrm{ns}$ & $\mathrm{ns}$ & ns \\
\hline $\mathrm{S} \times \mathrm{M}$ & $*$ & $*$ & ns & ns & $\mathrm{ns}$ & $*$ & ns & $*$ & ns & $*$ & $*$ & $*$ \\
\hline
\end{tabular}

\section{Discussion}

Excessive use of nitrate fertilizers has caused big problems in greenhouse soils in China ${ }^{[13,14]}$. The main problem is the secondary soil salinization. This is mainly attributed to the increasing demand of growers for higher and higher yielding. It is not denying that fertilizers, especially the nitrogen fertilizers are necessary for high crop yield and a moderately high soil EC benefits high quality of fruits such as tomatoes ${ }^{[47]}$. Research has shown that greenhouse tomato fruit quality has been improved by a moderately high EC in the nutrient solution without yield reduction by applying higher EC solution when the evapotranspiration demand is lower in the night and lower EC solution when the evapotranspiration demand is high at midday ${ }^{[48]}$. Health of crops can also be improved by stimulation with moderately high EC in the nutrient solution and this is called one of the applications of xerophytophysiology and signal transduction to plant production ${ }^{[49]}$. However, use of high EC is operated in hydroponic conditions without leaching of pollutants to the environment. In the soil-based greenhouses, the situation is different. Excessive fertilization in the soil-based greenhouses may cause many problems, such as accumulation of salts and the consequent salinization of the soil, pollutants leaching to the underground and surface waters ${ }^{[15,50]}$. Applications of organic and microbial materials have been tried in reducing the soil salinity ${ }^{[39]}$ caused by high content of sodium. However, it is needed to know whether or not applications of a microbial inoculant can reduce the damage caused by soil salinization from the excessive application of nitrogen fertilizers. Therefore, in Exp I of the present study, nitrate salts (NS) of $\mathrm{Ca}\left(\mathrm{NO}_{3}\right)_{2}$ and $\mathrm{KNO}_{3}$ was applied to potted tomato plants to simulate the soil salinity caused by excessive fertilization. The pot volume, with a soil surface of $0.05 \mathrm{~m}^{2}$ and a height of $0.3 \mathrm{~m}$, was large enough to supporting tomato fruiting. A microbial inoculant was used and expected to alleviate the damage caused by the soil salinity. One day after the treatment started, soil salinity caused by NS application really decreased the leaf water potential and leaf turgor potential at midday, induced the increase in superoxide radicals and cell membrane damage shown by high MDA concentration. However, as the treatment was prolonged for one week, activation of SOD was induced and consequently concentrations of $\mathrm{O}_{2}^{-}$and MDA were lowered to the normal levels. Three weeks after the treatments started, P-V curve was analyzed and the results showed that osmotic adjustment was induced and leaf turgor potential at no water stress was improved. The active increase in the concentration of osmolytes in addition to the turgor improvement suggested that osmotic adjustment surely occurred in response to soil salinity. The cell water fraction in symplasm was increased and that in apoplasm was reduced and this adjustment was favorable for the biochemical metabolism in the symplasm ${ }^{[51]}$. The osmotic potential at incipient plasmolysis or at zero turgor was lower in leaves of NS treated tomato plants than in the control. This suggested that NS application increased the water stress tolerance and maintained leaf turgor to severer stress level. As the treatment of NS application prolonged for weeks, up-regulation of the nitrate reductase (NR) gene and the consequent activation of nitrate reductase were induced. Therefore, despite the high total nitrogen content and deep leaf color, nitrate concentration was reduced as the NS treatment prolonged. The abovementioned results suggested that the tomato plants acclimated to the prolonged NS treatment at both physiological and molecular biological levels. As the nitrate was a necessary nutrient for tomato plants and the tomato plants acclimated to the soil salinity caused by NS treatment, fruit yield and total biomass production were still higher in NS treatment than in the control, despite the salinity stress and damage at the beginning. This is also the difference between salinities caused by nitrate salts and non-nitrate salts in the effect on plant production. In the successive studies with Exp II and Exp II, the same salinity as in Exp I and further severer salinity caused by nitrate salts and $\mathrm{NaCl}$ salt were designed. Comparison between salinities caused by nitrate salts and non-nitrate salts were made. Even at the same salinity level, salinity caused by $\mathrm{NaCl}$ could not show positive effect as nitrate salts did although both induced up-regulation expression of the stress-responsive gene and the consequent osmotic adjustment and activation of antioxidant enzymes. In addition to the positive osmotic adjustment, nitrate at the moderately high level improved biomass production. Even at the low applying rate, $\mathrm{NaCl}$ could not show positive effect on biomass production and consequently the osmotic adjustment ability was lower than that caused by nitrate salts because the osmotic adjustment should be a process consuming biomass and energy. In Exp III, where applying rate was doubled, NS did not show as much positive effect as that at low rate. $\mathrm{NaCl}$ salt at doubled applying rate salt showed worse effect on plant growth without real positive adaptation at both molecular and physiological levels. Even at the low applying level, NS salinity showed more positive effect on tomato plants in large pots than on those in small pots. The large volume might help tomato plant to better adapt to the salinity stress and favorite the stress-responsive regulations. Application of microbial inoculant was expected to alleviate the salinity damage no matter itself could or not show positive effect on the tomato crop. Actually, microbial inoculant 
application itself also improved the tomato crop yield and fruit quality by increasing the photosynthetic activities. Clarification of the detailed mechanisms for microbial inoculant effect in crop improvement was not planned in the present study and will be considered in the future studies. Application of microbial inoculant did not reduce the soil salinity shown by higher EC levels but did alleviate the salinity damage and synergistically increased the xerophytophysiological regulation caused by the soil salinity in addition to its positive effects on the tomato crop. There is also other research case that application of microorganisms cannot reduce soil salinity directly but alleviate salinity damage to the crops ${ }^{[51]}$. The microbial inoculant used in the present study contains lactic bacteria, yeasts, actinomycetes, photosynthetic bacteria as the main components with a $\mathrm{pH}$ of 3.5 in the original solution and it is different from other cases in both strain components and the chemical and physical properties of the final inoculant product. Further studies are needed to clarify how and what kinds of components in the inoculant contributed to the positive effects on the tomato plants under soil salinity caused by excessive application of nitrate fertilizers.

\section{Conclusions}

The following conclusions were drawn based on the results in the present study.

1) Application of nitrate salts at low rate induced salinity damage to potted tomato plants immediately after the treatment started. The tomato plants acclimated to the salinity stress by up-regulation expression of stress-responsive genes and the consequent xerophytophysiological regulations such osmotic adjustment and by activating antioxidant enzymes, nitrate reductase gene and the homological enzyme. As a necessary nutrient and cooperated with the xerophytophysiological regulations, nitrate salts at the low rate increased tomato fruit yield and the total plant biomass production despite of salinity stress.

2) However, salinity caused by application of $\mathrm{NaCl}$ did not show positive effect on tomato plants as nitrate salts did, although $\mathrm{NaCl}$, at low applying rate, also induce up-regulation of stress-responsive genes and xerophytophysiological regulations.

3) As the applying rate was doubled, nitrate salts did not show positive effect and $\mathrm{NaCl}$ showed severe damage effect on tomato plants.

4) Application of microbial inoculant alleviated damages at low salinity level but aggravated damages at high salinity level irrespective of its own positive effects to the tomato plants. Mechanisms for the effect of microbial inoculant need to be clarified in further studies.

\section{Acknowledgements}

This work was financially supported by China Postdoctoral Science Foundation Funded Project (51509068), the Fundamental Research Funds for the Central Universities (2018B00314, 2017B11014), and the China Postdoctoral Science Foundation (2017M611677).

\section{[References]}

[1] Heimann L, Roelcke M, Hou Y, Ostermann A, Ma W, Nieder R. Nutrients and pollutants in agricultural soils in the peri-urban region of Beijing: Status and recommendations. Agriculture Ecosystems \& Environment, 2015; 209: 74-88.

[2] Wang L, Wu X, Zhang Y, Li R, Chen L, Chen Q. Optimal nitrogen application rate to ensure cucumber and tomato yield with drip irrigation in greenhouse and to reduce soil salinity and nitrate residue. Transactions of the CSAE, 2015; 31(17): 91-98.

[3] Yang H, Cao H X, Hao X M, Guo L J, Li H Z, Wu X Y. Evaluation of tomato fruit quality response to water and nitrogen management under alternate partial root-zone irrigation. Int J Agric \& Biol Eng, 2017; 10(5): 85-94.

[4] Han J, Shi J, Zeng L, Xu J, Wu L Effects of nitrogen fertilization on the acidity and salinity of greenhouse soils. Environ Sci Pollut Res Int, 2015; 22(4): 2976-2986

[5] Kirchmann H, Johnston A E J, Bergström L F. Possibilities for reducing nitrate leaching from agricultural land. Ambio, 2014; 31: 404-408.

[6] Fan J, Hao M, Malhi S S. Accumulation of nitrate-N in the soil profile and its implications for the environment under dryland agriculture in northern China: A review. Can J Soil Sci, 2010; 90: 429-440.

[7] Rosas F, Babcock BA, Hayes DJ. Nitrous oxide emission reductions from cutting excessive nitrogen fertilizer applications. Climatic Change, 2015; 132(2): 353-367.

[8] Savci S. An agricultural pollutant: chemical fertilizer. Intl J Environ Sci Develop, 2012; 3(1): 77-80.

[9] Savci S. Investigation of Effect of Chemical Fertilizers on Environment. Apcbee Procedia, 2012; 1: 287-292

[10] Jiang H M, Zhang F, Yang J C, Liu Z H, Song X Z, Jiang H, Zhang X S. Effects of different models of applying nitrogen fertilizer on yield and quality of tomato and soil fertility in greenhouse. Plant Nutr Fert Sci, 2010; 16(1): 158-165.

[11] Eraslan F, Elkarim HA, Karim A, Gunes A, Inal A. Effect of nutrient induced salinity on growth, membrane permeability, nitrate reductase activity, proline content and macronutrient concentrations of tomato grown in greenhouse. World Acad Sci Engin Technol, 2012; 71: 1915-1919.

[12] Wang Y, Li K, Tanaka T S T, Yang D, Inamura T. Soil nitrate accumulation and leaching to groundwater during the entire vegetable phase following conversion from paddy rice. Nutrient Cycling in Agroecosystems, 2016; 106 (3): 325-334.

[13] Shi W M, Yao J, Yan F. Vegetable cultivation under greenhouse conditions leads to rapid accumulation of nutrients, acidification and salinity of soils and groundwater contamination in South-Eastern China. Nutrient Cycling in Agroecosystems, 2009; 83(1): 73-84.

[14] Jurišic A, Zgorelec Z, Šestak, I, Mesic M, Mikoč V. Nitrate-nitrogen content in soil and lysimeter water under different nitrogen fertilization levels in crop production. Agriculturae Conspectus Scientificus, 2014; 79(1): 45-50.

[15] Li J L, Cui D J, Meng X X, Li X L, Zhang F S. The study of fertilization condition and question in protectorate vegetable in Shouguang, Shandong. Chinese J Soil Sci, 2002; 2: 126-128. (in Chinese)

[16] Wang Z H, Liao R K, Lin H, Jiang G J, He X L, Wu W Y, et al. Effects of drip irrigation levels on soil water, salinity and wheat growth in North China. Int J Agric \& Biol Eng, 2018; 11(1): 146-156.

[17] Amini F, Akbar A. Soluble proteins, proline, carbohydrates and $\mathrm{Na}+/ \mathrm{K}+$ changes in two tomato (Lycopersicon esculentum Mill.) cultivars under in vitro salt stress. Amer J Biochem Biotechnol, 2005; 1(4): 212-216.

[18] Kamaluldeen J, Yunusa IAM, Zerihun A, Bruhl JJ, Kristiansen P. Uptake and distribution of ions reveal contrasting tolerance mechanisms for soil and water salinity in okra (Abelmoschus esculentus) and tomato (Solanum esculentum). Agricultural Water Management, 2014; 146: 95-104.

[19] Qasim M, Ashraf M, Ashraf M Y, Ahmad N. Relationship of biomass production with nitrate assimilation in canola (Brassica napus L.) under salinity stress. Intl J Agr Biol, 2002; 4(4): 521-522.

[20] Maggio A, Raimondi G, Martino A, De Pascale S. Salt stress response in tomato beyond the salinity tolerance threshold. Environ Exp Bot. 2007; 59: 276-282.

[21] Umebese C E, Olatimilehin T O, Ogunsusi T A. Salicylic acid protects nitrate reductase activity, growth and proline in amaranth and tomato plants during water deficit. Amer J Agr Biol Sci, 2009; 4: 224-229.

[22] Kavoosi G, Balotf S, Eshghi H, Hasani H. Analysis of nitrate reductase mRNA expression and nitrate reductase activity in response to nitrogen supply. Molecular Biology Research Communications, 2014; 3(2): 366-369.

[23] Montaigu A D, Sanz-Luque E, Galván A, Fernández E. A soluble guanylate cyclase mediates negative signaling by ammonium on expression of nitrate reductase in Chlamydomonas. Plant Cell, 2010; 22: $1532-1548$

[24] Konishi M, Yanagisawa S. The regulatory region controlling the 
nitrate-responsive expression of a nitrate reductase gene, $\mathrm{NiA} 1$, in Arabidopsis. Plant Cell Physiol, 2011; 52: 824-836.

[25] Frías J E, Flores E. Induction of the Nitrate Assimilation nirA Operon and Protein-Protein Interactions in the Maturation of Nitrate and Nitrite Reductases in the Cyanobacterium Anabaena sp. Strain PCC 7120. (PMID:25962912 PMCID:PMC4524197). Journal of Bacteriology, 2015; 197(14): 2442.

[26] Bowles T M. Root expression of nitrogen metabolism genes reflects soil nitrogen cycling in an organic agroecosystem. Plant \& Soil, 2015; 392 (1-2): 175-189.

[27] Debouba M, Dguimi H M, Ghorbel M, Gouia H, Suzuki A. Expression pattern of genes encoding nitrate and ammonium assimilating enzymes in Arabidopsis thaliana exposed to short term $\mathrm{NaCl}$ stress. Journal of Plant Physiology, 2013; 170(2): 155.

[28] Yang X Y, Wang X F, Wei M, Yang F J, Shi Q H. Changes of nitrate reductase activity in cucumber seedlings in response to nitrate stress. Agr Sci China, 2010; 9(2): 216-222.

[29] Kavoosi G, Balotf S, Eshghi H, Hasani H. Analysis of nitrate reductase mRNA expression and nitrate reductase activity in response to nitrogen supply. Mol Biol Res Commun, 2014; 3(2): 75-84.

[30] Guo J, Wang M H. Expression profiling of the DREB2 type gene from tomato (Solanum lycopersicum L.) under various abiotic stresses. Hort Environ Biotechnol, 2011; 52(1): 105-111.

[31] Thameur A, Ferchichi A, LópezCarbonell M. Involvement of abscisic acid metabolites and the oxidative status of barley genotypes in response to drought. Canadian Journal of Plant Science, 2014; 94(8): 1481-1490.

[32] Bissenbaev A K, Altybaeva N A, Kolbaeva G A. Role of reactive oxygen species and antioxidants enzymes in hormone regulating programmed cell death of wheat aleurone layer. J Cell Molec Biol, 2007; 6(1): 41-48.

[33] Chang T, Shao X, Zhang J, Zhang Z, Ye H. Influence of subsurface drainage on soil salinity, soil moisture, and summer tomato yield in a low-lying greenhouse soil, China. 2016 American Society of Agricultural and Biological Engineers Annual International Meeting, ASABE, 2016

[34] Singh R K, Redoña E, Refuerzo L. Varietal Improvement for Abiotic Stress Tolerance in Crop Plants: Special Reference to Salinity in Rice. In: Pareek A, Sopory S, Bohnert H (eds) Abiotic Stress Adaptation in Plants. Springer, Dordrecht, 2009, pp.387-415.

[35] Freedman A, Gross A, Shelef O, Rachmilevitch S, Arnon S. Salt uptake and evapotranspiration under arid conditions in horizontal subsurface flow constructed wetland planted with halophytes. Ecol Engineer, 2014; 70: 282-286.

[36] Bashan Y. Inoculants of plant growth-promoting bacteria for use in agriculture. Biotechnol Adv, 1998; 16: 729-770.

[37] Dodd I C, Perez-Alfocea F. Microbial amelioration of crop salinity stress.
J Exp Bot, 2012; 63: 3415-3428.

[38] Mayak S, Tirosh T, Glick B R. Plant growth-promoting bacteria that confer resistance to water stress in tomato and pepper. Plant Sci, 2004, 166: 525-530.

[39] Kato T, Xu H L, Syed A. Utilizing Microorganisms bioremediation of salt-saturated agricultural land: introducing cases in Pakistan and China. J Arid Land Studies, 2005; 15(1): 55-59.

[40] Xu H L, Xu Q C, Li F L, Feng Y Z, Qin F F, Fang W. Applications of xerophytophysiology in plant production-LED blue light as a stimulus improved the tomato crop. Sci Hort, 2012; 148: 190-196.

[41] Jones H G. Plants and Microclimate: A Quantitative Approach to Environmental Plant Physiology (2nd Ed.). Cambridge University Press, 1992; 428p

[42] Beyer W F, Fridovich I. Assaying for superoxide dismutase activity: some large consequences of minor changes in condition. Anal Biochem, 1987; 161: 559-566

[43] Chakrabarty D, Verma A K, Datta S K. Oxidative stress and antioxidant activity as the basis of senescence in Hemerocallis (day lily) flowers. J Hort Forest, 2009; 1(16): 113-119.

[44] Heath R L, Packer L. Photoperoxidation in isolated chloroplasts. I. Kinetics and stoichiometry of fatty acid and peroxidation. Arch Biochem Biophys, 1968; 125: 189-198.

[45] Dey S K, Dey J, Patra S, Pothal D. Changes in the antioxidative enzyme activities and lipid peroxidation in wheat seedlings exposed to cadmium and lead stress. Braz J Plant Physiol, 2007; 19: 53-60.

[46] Tang Q Y, Feng M G. DPS Data Processing System - Experimental Design, Statistical Analysis and Data Mining. Science Press, Beijing, 2006.

[47] $\mathrm{Xu} \mathrm{H} \mathrm{L,} \mathrm{Gauthier} \mathrm{L,} \mathrm{Gosselin} \mathrm{A.} \mathrm{Greenhouse} \mathrm{tomato} \mathrm{photosynthetic}$ acclimation to water deficit and response to salt accumulation in the substrate. J Japan Soc Hort Sci, 1997; 65: 777-784.

[48] Xu H L, Gauthier L, Gosselin A. Effects of fertigation management on growth and photosynthesis of tomato plants grown in peat, rockwool and NFT. Sci Hort, 1995; 63: 11-20.

[49] Xu H L. Xerophytophysiology in crop production. In: Xu, H.L. (Ed.), Dryland Crop Production - Technology Breakthroughs and Study Cases. Research Signpost, Kerala (India), 2007; pp.37-54.

[50] Han J, Shi J, Zeng L, Xu J, Wu L. Impacts of continuous excessive fertilization on soil potential nitrification activity and nitrifying microbial community dynamics in greenhouse system. Journal of Soils \& Sediments, 2017; 17(2): 471-480.

[51] Miransari M. Mycorrhizal Fungi to Alleviate Salinity Stress on Plant Growth. Springer, New York, 2014; pp.77-86.

[52] Stowell L. Efficacy of microbes in soil salinity reduction. PACE Consulting, 2005. Available at https://www.paceturf.org/ PTRI/.../Micro_94.PDF. 